\title{
THERMIONIC IRRADIATIONS PROGRAM
}

\author{
FINAL REPORT
}

\author{
by \\ PROJECT STAFF
}

\author{
Prepared under \\ Contract DE-AC03-85SF15953 \\ for the San Francisco Operations Office \\ Department of Energy
}

JULY 1987

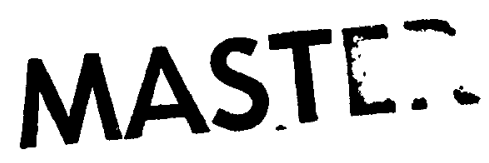

DISTRIBUTION OF THIS OOCUMENT IS UNLIMITED

$P D$ 


\section{DISCLAIMER}

This report was prepared as an account of work sponsored by an agency of the United States Government. Neither the United States Government nor any agency Thereof, nor any of their employees, makes any warranty, express or implied, or assumes any legal liability or responsibility for the accuracy, completeness, or usefulness of any information, apparatus, product, or process disclosed, or represents that its use would not infringe privately owned rights. Reference herein to any specific commercial product, process, or service by trade name, trademark, manufacturer, or otherwise does not necessarily constitute or imply its endorsement, recommendation, or favoring by the United States Government or any agency thereof. The views and opinions of authors expressed herein do not necessarily state or reflect those of the United States Government or any agency thereof. 


\section{DISCLAIMER}

Portions of this document may be illegible in electronic image products. Images are produced from the best available original document. 
This report was prepared as an account of work sponsored by an agency of the United States Government. Neither the United States Government nor any agency thereof, nor any of their employees, makes any warranty, express or implied, or assumes any legal liability or responsibility for the accuracy, completeness, or usefulness of any information, apparatus, product, or process digclosed, or represents that its use would not infringe privately owned rights. Reference herein to any specific commercial product, process, or service by trade name, trademark, manufacturer, or otherwise, does not necessarly congtitute or imply its endorsement, recommendation, or favoring by the United States Government or any agency thereof. The views and opinions of authors expressed herein do not necessarily state or reflect those of the United States Government or any agency thereof.

\author{
Printed in the United States of America \\ Avallable from \\ National Technical Information Service \\ U.S. Department of Commerce \\ 5285 Port Royal Road \\ Springfield, Virginia 22161 \\ Price Code: Printed Copy A04; Microfiche A01
}


GA-A18916

UC-97d

\title{
THERMIONIC IRRADIATIONS PROGRAM
}

\author{
FINAL REPORT
}

\author{
by \\ PROJECT STAFF
}

\author{
Prepared under \\ Contract DE-AC03-85SF15953 \\ for the San Francisco Operations Office \\ Department of Energy
}

GA PROJECT 3438

JULY 1987 
1. INTRODUCTION . . . . . . . . . . . . . . . 1

2. FUELED EMITTER IRRADIATION . . . . . . . . . . . . . 3

2.1 TEST DESCRIPTION . . . . . . . . . . . . . . . . . 3

2.2 SUMMARY OF THE IRRADIATION TESTING . . . . . . . . . . 8

2.2.1 TRIGA Operation . . . . . . . . . . . . 8

2.2.2 Thermionic Capsules Operation .......... 10

3. SHEATH INSULATOR IRRADIATION TESTING . . . . . . . . . . . 11

3.1 SUMMARY OF IRRADIATION TESTING . . . . . . . . . . . . . . 11

3.2 REMOVAL OF CAPSULE 4 FROM TRIGA MARK F CORE . . . . . . . . 19

4. TEST DATA INTERPRETATION ........................ 21

4.1 TRIGA IRRADIATION CONDITIONS . . . . . . . . . . . . 21

4.1.1 Diode Operating Power . . . . . . . . . . 23

4.2 LIFE CODE RESULTS . . . . . . . . . . . . . . . . . 29

5. NEUTRON RADIOGRAPHY . . . . . . . . . . . . . . 41

5.1 NEUTRON RADIOGRAPHY PROCEDURE .............. 41

APPENDIX A . . . . . . . . . . . . . . . 45 


\section{INTRODUCTION}

During the 1970s, the TFE development was consistent with the 20,000-hour lifetime goal used at that time. Primary life-limiting factors were recognized to be (1) thermionic emitter dimensional increases due to swelling of the $\mathrm{OO}_{2}$ fuel, and (2) electrical insulator structural damage from fast neutrons. Unrestricted emltter dimensional increases result in shorting of the converter electrodes, thereby reducing the output voltage of the shorted cell. Structural fallure of an insulator seal results in a mixing of the fission gases with the cesium vapor. Structural failure of the sheath insulator can result in increased collector temperatures and less than optimal performance. The effect of a crack in the insulator may have an effect on the electrical properties but not thermal properties.

In the SP-100 (Phase I) program, the baseline approach to a resolution of the fueled emitter issue was to adjust the converter design: the emitter temperature in the baseline design was reduced from the 1800-2000 $\mathrm{K}$ values used in the earlier program to an average of $1740 \mathrm{~K}$; the emitter thickness was increased from $40 \mathrm{mils}$ to $70 \mathrm{mils}$ to further reduce distortion; and the gap between emitter and collector was doubled to $20 \mathrm{mils}$. The profected lifetime was greater than the required 7 years.

The baseline approach to a resolution of the insulator issue was to change the insulator materials from $\mathrm{Al}_{2} \mathrm{O}_{3}$ to $\mathrm{Y}_{2} \mathrm{O}_{3} \cdot$ Both $\mathrm{Y}_{2} \mathrm{O}_{3}$ and $\mathrm{Y}_{3} \mathrm{Al}_{5} \mathrm{O}_{12}$ (YAG) have been demonstrated in fusion programs to be dimensionally stable in fast neutron fluences that exceed thermionic reactor requirements. With these ceramics, growth to larger systems will not be limited by neutron damage effects.

Technology alternatives to the baseline approach Include YAG and stress relieved $\mathrm{Al}_{2} \mathrm{O}_{3}$. YAG insulators have suffered from radial cracking during recent fabrication development. Resolution of the cracking problem will require continued process development but not mafor technology innovations. 
The Thermionic Technology Program (TTP) was a part of Phase I of the SP-100 program and addressed the technology issues of the TFE. Experimental verification that the TFE lifetime was, with high probability, at least 7 years was the goal of the TTP program. Both fueled emitters and insulators were fabricated and tested, and program results were documented in a final report, GA-A18182, "SP-100 Thermionic Technology Program", November, 1985.

Nine fueled emitters contained in 3 irradiation capsules were designed, fabricated and inserted into the TRIGA during the TTP program. The purpose of the irradiations is to study emitter distortion as a function of emitter temperature and emftter thickness, and to develop appropriate lifeperformance models. Also, as a part of the SP-100 program, an insulator capsule containing several insulator test articles was also inserted into TRIGA, the purpose being to study insulator integrity under irradiation and an applied voltage.

The SP-100 (Phase I) program ended at the end of FY-85. The Irradiation of the 9 fueled emitters and the insulator test specimens continued in FY-86 under a separate DOE program, the Thermionics Irradiation Program, Contract DE-AC03-85SF15933. In FY-87 and beyond, the irradiations will continue as part of the TFE Verification Program to provide data for megawatt class thermionic systems.

This report describes the testing and modeling of the fueled emitters and sheath insulator samples during FY-86. This is the final report under DOE Contract DE-ACO3-85SF15953. 


\section{FUELED EMITTER IRRADIATION}

Nine thermionic emitters fueled with uranium oxide are being tested in the TRIGA Mark F reactor to measure emitter deformation as a function of emitter temperature, emitter thickness, and operating profile and to determine dominant deformation mechanisms. The deformation data will be used to validate fuel models and viscoelastic analyses, which will establish the design of fueled emitters for 7-year operation.

The work performed as part of the TTP in the previous periods, FY-84 and FY-85, concentrated on the design and fabrication of the fueled emitter test diodes, their test capsules and the modiflcation and instrumentation of the TRIGA Mark F reactor.

\subsection{TEST DESCRIPTION}

Each emitter was fabricated into a thermionic converter with the design configuration shown in Figs. 1-1 and 1-2. A separate converter was used to test each emitter to insure that the planned test conditions could be independently controlled and monitored. Three emitters were assembled into each irradiation capsule as shown in Fig. 1-3. Each emftter has 1ts own ceslum reservoir with heaters for temperature control and a large plenum with a pressure tap to collect and monitor the fission gas released from the fuel. Instrumentation for the capsule includes thermocouples for temperature measurement of the emitter flange, the collector and cesium reservolr; voltage taps for the emitter and collector; and power leads for the cesium reservoir heaters.

The conditions chosen for testing centered around the reference SP-100 emitter design point of $27.9 \mathrm{~mm}$ diameter, $1.78 \mathrm{~mm}$ thickness, and $1750 \mathrm{~K}$ peak temperature. The test matrix is shown in Table 1-1. It contains three emitter temperatures $(1650,1750$, and $1850 \mathrm{~K})$ and three thicknesses $(1.02$, 1.78, and 2.54). Six of the nine emitters operate at about $1750 \mathrm{~K}$ to maximize the data around the design point. Three of these six emitters are to be at the reference 1.78 mickness, two have a thicker emitter at 


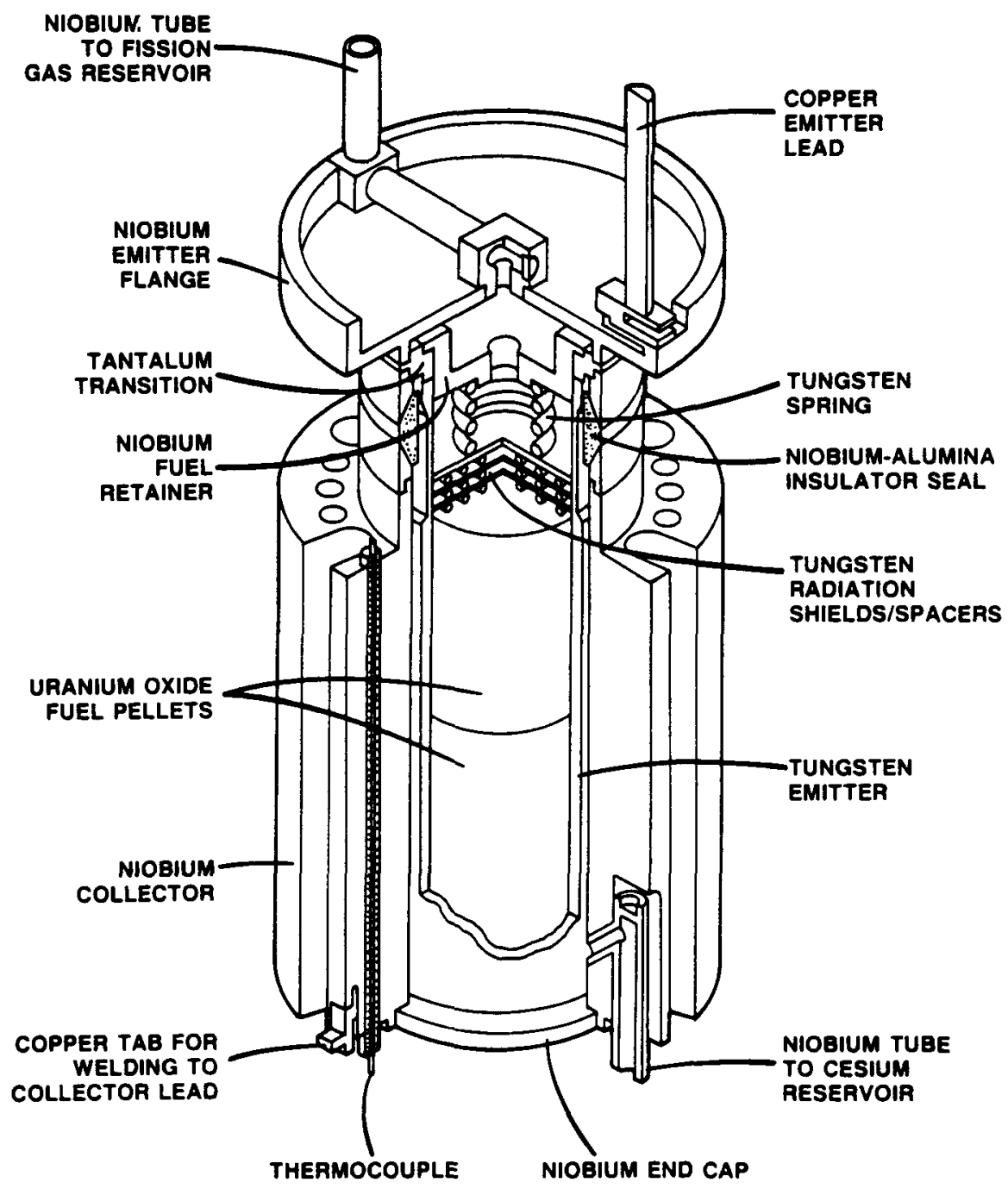

Figure 1-1. Thermionic converter test article. 


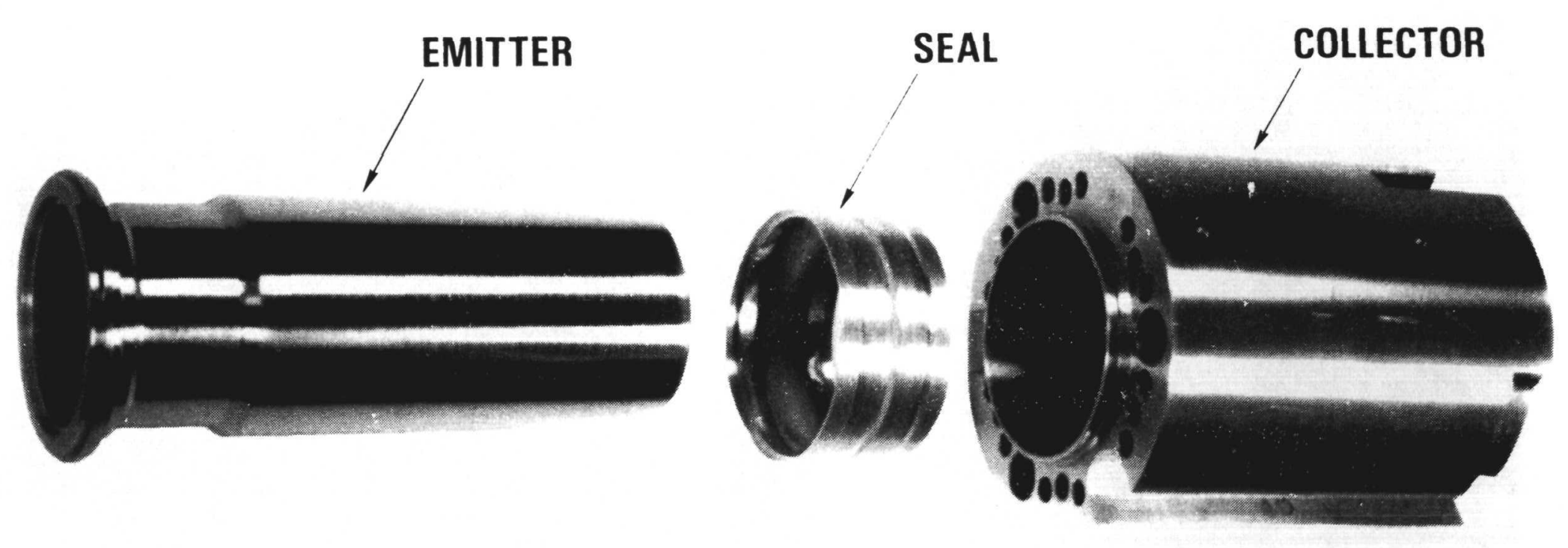

G-803(1)

Figure 1-2. Fueled emitter capsule design 


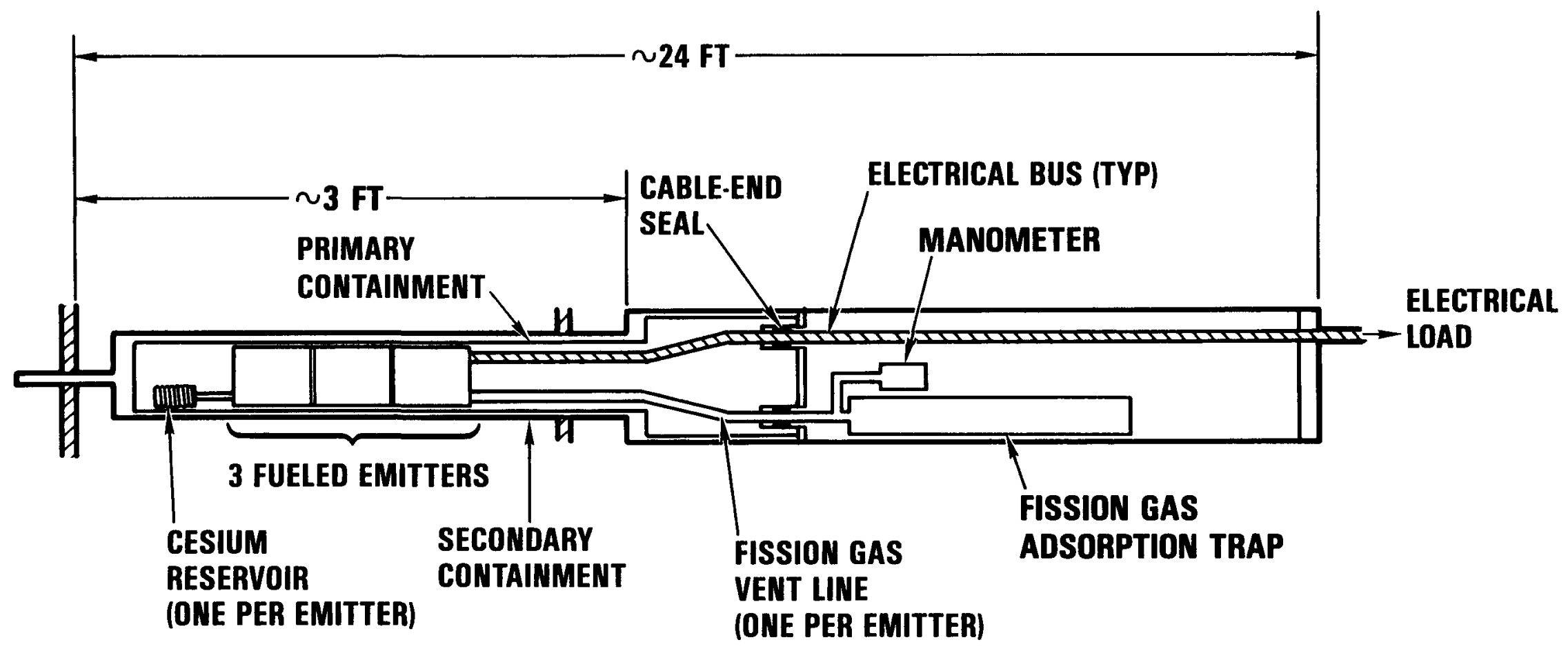

Figure 1-3. Fueled emitter capsule schematic. 
TABLE 1-1

FUELED EMITTER TEST PARAMETERS

\begin{tabular}{|c|c|c|c|c|c|c|}
\hline $\begin{array}{l}\text { Capsule } \\
\text { Number }\end{array}$ & $\begin{array}{l}\text { Converter } \\
\text { Position }\end{array}$ & $\begin{array}{c}\text { Emitter } \\
\text { Temperature } \\
\text { (K) }\end{array}$ & $\begin{array}{c}\text { Emitter } \\
\text { Wal1 Thickness } \\
\text { (in.) }\end{array}$ & $\begin{array}{l}\text { Emitter } \\
\text { i.d. } \\
\text { (in.) }\end{array}$ & $\begin{array}{l}\text { Fuel Pellet } \\
\text { o.d. } \\
\text { (in.) }\end{array}$ & $\begin{array}{l}\text { Emitter } \\
\text { Power } \\
\text { (w) }\end{array}$ \\
\hline \multirow[t]{3}{*}{1} & Top & 1750 & 0.100 & 0.900 & 0.883 & 700 \\
\hline & Middle & 1850 & 0.100 & 0.900 & 0.880 & 1040 \\
\hline & Bottom & 1750 & 0.100 & 0.900 & 0.883 & 830 \\
\hline \multirow[t]{3}{*}{2} & Top & 1650 & 0.070 & 0.960 & 0.944 & 620 \\
\hline & Middle & 1850 & 0.070 & 0.960 & 0.939 & 1110 \\
\hline & Bottom & 1750 & 0.070 & 0.960 & 0.942 & 905 \\
\hline \multirow[t]{3}{*}{3} & Top & 1750 & 0.040 & 1.020 & 1.001 & 1100 \\
\hline & Middle & 1750 & 0.070 & 0.960 & 0.942 & 1190 \\
\hline & Bottom & 1750 & 0.070 & 0.960 & 0.942 & 1035 \\
\hline
\end{tabular}


$2.54 \mathrm{man}$ and one is thinner with a $1.0 \mathrm{~mm}$ emitter. The other three emitters are at various combinations of temperature and thickness as shown in the table.

\subsection{SUMMARY OF THE IRRADIATION TESTING}

Irradiation testing of the fuel emitters was initiated on January 13, 1985, with the installation of Capsule 2 in the TRIGA Mark F. Capsule 1 followed shortly after with 1ts installation on February 21, 1985.

Capsule 3 was installed on July 19, 1985. Capsule 4, the insulator test capsule was installed on September 27, 1987. During FY-86, a total of 7491 hours of irradiation testing was logged by each emitter. The irradiation exposure as of January 5, 1987, is sumarlzed in Table 2-1. A detailed history of the frradiation since its inception through January 5, 1987, is included in Appendix A.

\subsubsection{TRIGA Operation}

The operation of the TRIGA Mark F reactor was very stable during the reporting period with an extremely high availability of 98.5\%. A few TRIGA-related scrams were experienced but did not cause extended shutdowns. Generally, startup and full power operation was achieved within the same day.

The TRIGA Mark F operated with about $\$ 1.50$ excess reactivity during parts of calendar years 1985 and 1986 to accommodate the additional thermionic capsules and provide operating flexibility. This excess reactivity was reduced during the July/August 1986 annual TRIGA fuel inspection. The core was reconfigured by removing 6 fuel elements. This lowered the excess reactivity to the thermionic design value of less than $\$ 0.50$. The core had to be reconfigured again following the removal of Capsule 4 from the core on August 13, 1987. Four additional fuel elements were removed to maintain the excess to less than $\$ 0.50$.

Operation with the additional excess reactivity required the control rods to be inserted into the core below the level of the upper thermionic 
TABLE 2-1

TRIGA IRRADIATION EXPERIMENT STATUS

\begin{tabular}{|c|c|c|c|c|c|c|}
\hline & \multicolumn{2}{|c|}{$\begin{array}{c}\text { CAPSULE } 1 \\
\mathrm{~T}=13,934 \text { HRS } \\
\end{array}$} & \multicolumn{2}{|c|}{$\begin{array}{c}\text { CAPSULE } 2 \\
\mathrm{~T}=14,764 \text { HRS } \\
\end{array}$} & \multicolumn{2}{|c|}{$\begin{array}{c}\text { CAPSULE } 3 \\
\mathrm{~T}=10,789 \text { HRS } \\
\end{array}$} \\
\hline & $\begin{array}{c}\text { FLUENCE } \\
\left(\mathrm{nv} \times 10^{-21}\right) \\
\mathrm{E}>0.1 \mathrm{MeV}\end{array}$ & $\begin{array}{l}\text { BURNUP } \\
\text { ATOM } \\
\text { PERCENT }\end{array}$ & $\begin{array}{c}\text { FLUENCE } \\
\left(\mathrm{nv} \times 10^{-21}\right) \\
\mathrm{E}>0.1 \mathrm{MeV}\end{array}$ & $\begin{array}{l}\text { BURNUP } \\
\text { ATOM } \\
\text { PERCENT }\end{array}$ & $\begin{array}{c}\text { FLUENCE } \\
\text { (nv } \times 10^{-21} \text { ) } \\
E>0.1 \mathrm{MeV}\end{array}$ & $\begin{array}{c}\text { BURNUP } \\
\text { ATOM } \\
\text { PERCENT }\end{array}$ \\
\hline CELL 1 & 1.11 & 0.24 & 1.18 & 0.19 & 0.77 & 0.23 \\
\hline CELL 2 & 1.46 & 0.36 & 1.54 & 0.36 & 1.01 & 0.27 \\
\hline CELL 3 & 1.11 & 0.28 & 1.18 & 0.30 & 0.77 & 0.25 \\
\hline
\end{tabular}


diodes. The inserted rods cause skewing of the axial power distribution with an associated uncertainty in the power levels of all diodes. The effect of this skew on the individual diode power is currently being evaluated. Since the reconfiguring of the core, all cells are well below the absorber section of the control rods and, therefore, operating in a much flatter axial power distribution.

\subsubsection{Thermionic Capsules Operation}

The three thermionic-fueled emitter capsules operated exceptionally well during the reporting perlod. There were no fueled emitter capsulerelated scrams. Outlined below is the status of the nine emitter diodes as of January 5, 1987.

a) S1x of 9 diodes, specifically, $1.2,2.1,2.3,3.1,3.2$, and 3.3 continue to operate normally.

b) Diode 1.1 has a partial short external to the thermionic diode. The design emitter temperature of $1750 \mathrm{~K}$ is probably being maintained, so valid distortion data are still being obtained.

c) Diode 1.3 appears to have helium in the interelectrode gap since December, 1985. The emitter temperature is probably less than the design of $1750 \mathrm{~K}$ because of the high thermal conductivity of helium. No I-V data can be obtained for this diode because of its very high resistance.

d) Dlode 2.2 operated with somewhat unpredictable conditions. The voltage varled spurfously between positive and negative values during the reporting period. The estimated emitter temperatures ranged from 1850 to 1650 and then back to $1850 \mathrm{~K}$.

e) The pressure transducers on six of the cells yield data on fission gas release. Data from cells $1.1,1.2$ and 3.2 do not appear valld and 1 is belleved that this reflects problems that occurred during initial fabrication and assembly. 


\section{SHEATH INSULATOR IRRADIATION TESTING}

The design concept of the incore sheath insulator capsule is 11lustrated in Fig. 3-1. The sheath insulator samples are stacked along a common axis inside a vacuum chamber formed by a stainless steel containment tube. The insulators are heated from two sources: (1) by gamma radiation within the bulk material of each insulator and (2) by thermal radiation from a separate gamma-heated tantalum cylinder inside the stack of sheath insulators. A cylindrical stainless-steel water cooled cold finger is located inside the tantalum gamma heater and argon gas gap exists between the two. The temperature of the tantalum heater and thus the temperature of the insulators is controlled by changing the gas mixture in this gap. The thermal impedance of the capsule is designed to give a nominal sample temperature of $1100 \mathrm{~K}$ with argon and about $925 \mathrm{~K}$ with helium.

Eight chromel-alumel thermocouples are provided for temperature measurement of the samples and tantalum heater. The sheaths on four of these are used as insulator voltage probes. Isolated wires serve as current leads for each electrically loaded sample or guard ring. One isolated wire, identical to a sample current lead but left unconnected in the core, is used to measure a representative leakage current.

Six sheath insulator samples were installed for testing, five to be electrically loaded and one to be irradiated without electric field. Four of the insulator samples were yttria, two were alumina. The electrically loaded samples were qualified in out-of-core thermal and electrical stability tests prior to installation. Figure 3-2 shows the general configuration of the samples and Table 3-1 describes the samples and their qualifications testing.

\subsection{SUMMARY OF IRRADIATION TESTING}

Capsule 4 was installed in the TRIGA reactor and testing was initiated on September 27, 1985. Capsule vacuum was very good, reaching $3 \times 10^{-6}$ torr at temperature. Initially, helium gas was used in the gas gap between the 


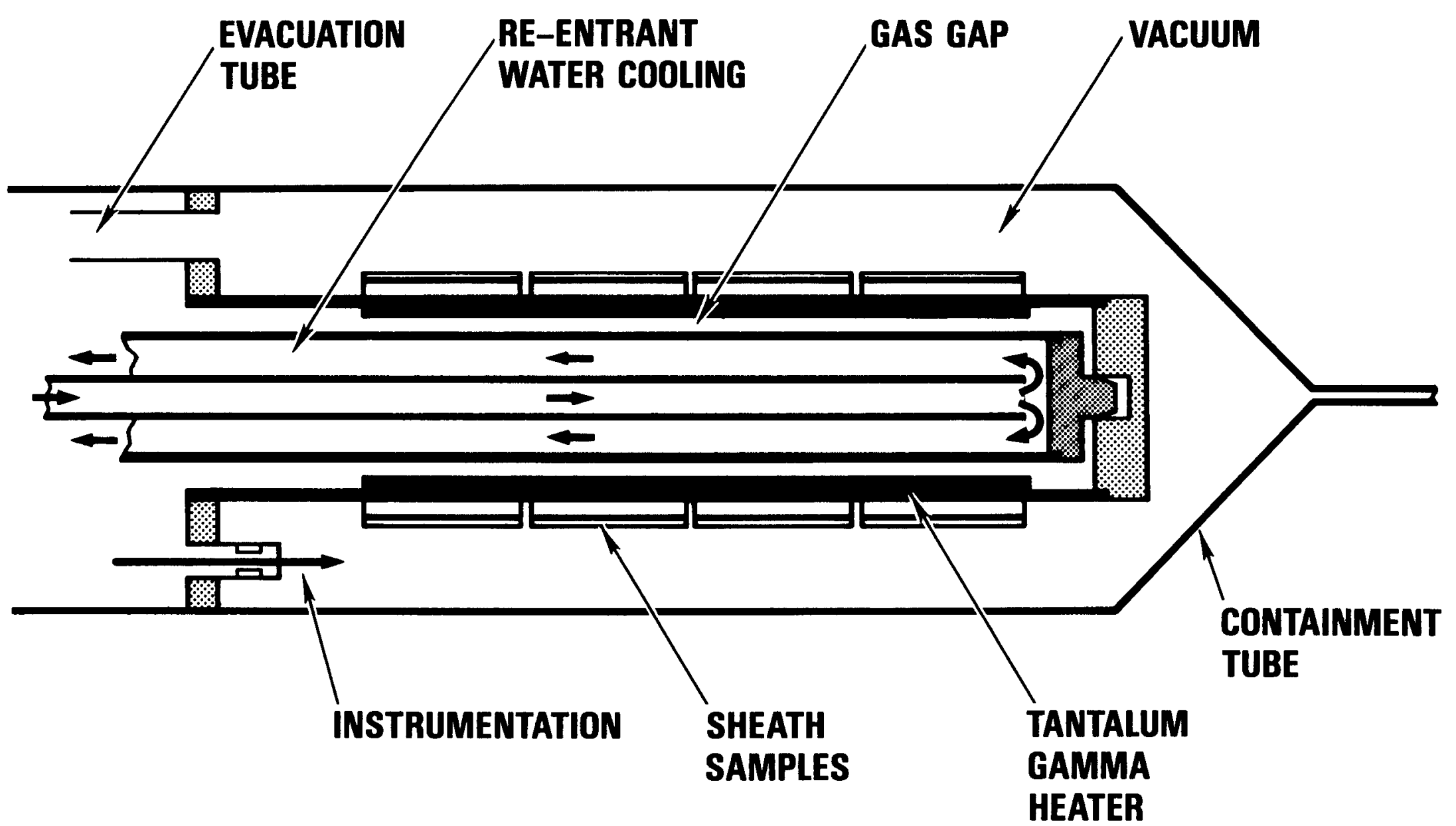

Figure 3-1. Sheath insulator in-core test design concept. 


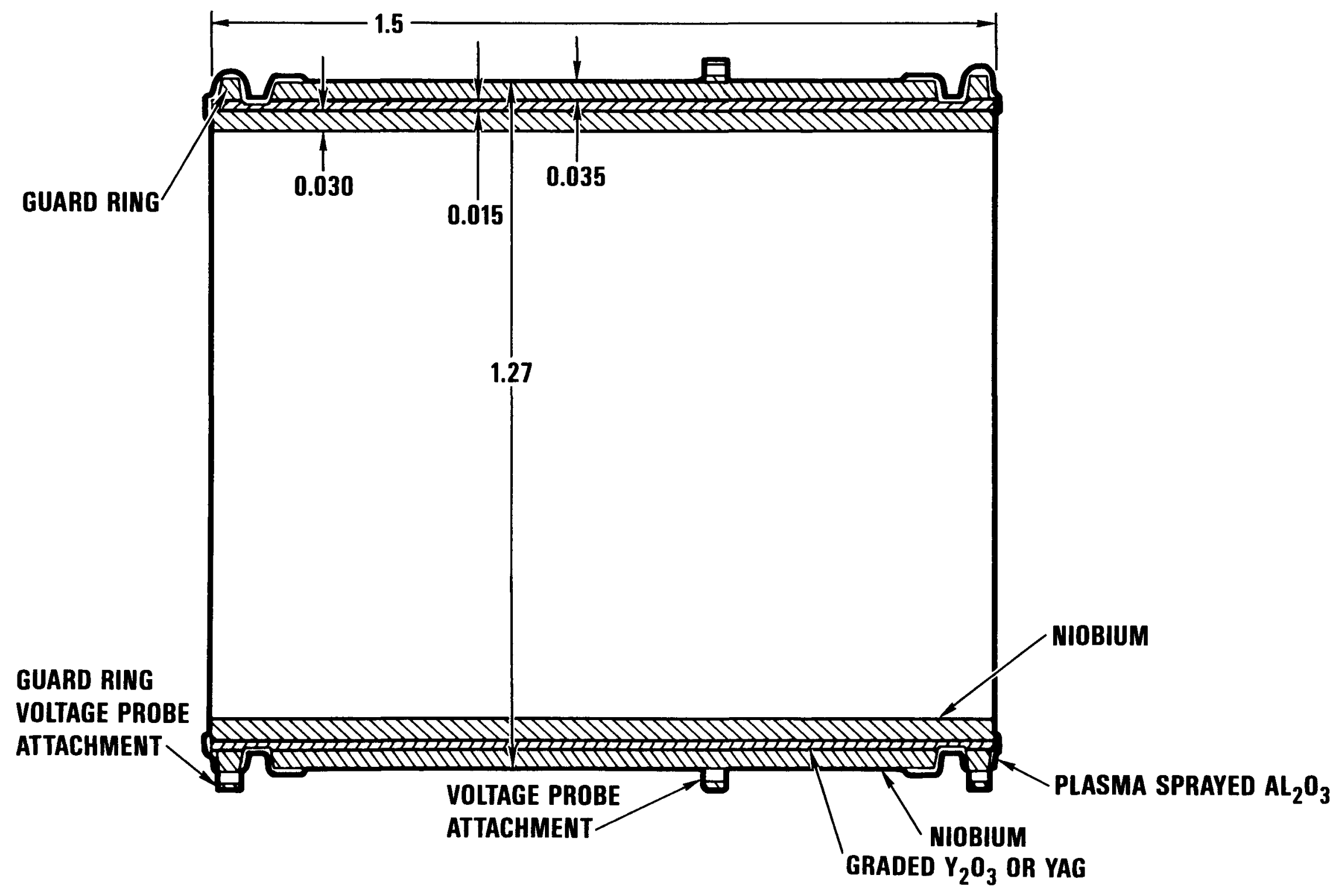

Figure 3-2. TRIGA insulator capsule irradiation test specimen. 
TABLE 3-1

TRIGA IRRADIATION EXPERIMENT INSULATORS TEXT MATRIX

\begin{tabular}{|c|c|c|c|c|c|c|c|}
\hline SAMPLE & MATERIAL & $\begin{array}{c}\text { LENGTH } \\
\text { (in.) }\end{array}$ & $\begin{array}{c}\text { TEMPERATURE } \\
{ }^{\circ} \mathrm{C}\end{array}$ & $\begin{array}{c}\text { APPLIED } \\
\text { VOLTAGE } \\
V\end{array}$ & $\begin{array}{c}\text { CURRENT } \\
\text { (mA) }\end{array}$ & $\begin{array}{c}\phi \\
\text { nVt } \times 10^{-13}\end{array}$ & $\begin{array}{c}\text { RESISTIVITY } \\
\text { M } \Omega \text {-cm }\end{array}$ \\
\hline 1 & $\mathrm{Al}_{2} \mathrm{O}_{3}$ & 0.31 & 761.0 & 9.98 & 0.021 & 2.59 & 177.5 \\
2 & $\mathrm{Y}_{2} \mathrm{O}_{3}$ & 0.18 & 758.0 & 9.96 & 1.566 & 2.59 & 1.4 \\
3 & $\mathrm{Al}_{2} \mathrm{O}_{3}$ & 0.68 & 763.0 & 9.96 & 1.220 & 2.61 & 6.6 \\
4 & $\mathrm{Y}_{2} \mathrm{O}_{3}$ & 0.75 & 751.0 & 1.01 & 3.49 & 2.57 & 0.26 \\
5 & $\mathrm{Y}_{2} \mathrm{O}_{3}$ & 1.30 & 716.0 & 9.94 & 1.97 & 2.45 & 7.5 \\
\hline
\end{tabular}

IRRADIATION TIME: 6450 HRS. 
water cooling cold finger and tantalum heater. This resulted in a maximum sample temperature of $717 \mathrm{~K}$.

The generation of hydrogen gas in the water resulted in bubble formation which led to several early scrams before the problem was identified and resolved (see Appendix A). During these perlods, the gas in the gap was changed from helium to argon, resulting in insulator temperatures near $1030 \mathrm{~K}$, slightly lower than the $1100 \mathrm{~K}$ target.

All samples inftially had high electrical conductivities compared to their qualification test values. The resistivity of samples 2 through 5 Increased slowly during the flrst 2000 hours of operation and then reached stable steady state values which were stable for the next 3000 hours, Fig. 3-3. The resistivity of alumina sample 1 increased significantly by two orders of magnitude during this same period and also reached and sustained a stable steady state operating point for the next 1000 hours, Fig. 3-4. The nature of these resistivity changes is not known, but they are probably associated with end losses and the cleanup of the ends with time.

A change occurred in the resistivity of samples 2, 4, and 5, all $\mathrm{Y}_{2} \mathrm{O}_{3}$, at about 5000 hours. At this point a drop in sample temperature of about $50^{\circ} \mathrm{C}, \mathrm{Fig} .3-5$, and a corresponding increase in resistivity was observed. Several operational means of increasing the temperature were tried including pump downs of the vacuum gap and a changeout of the argon in the temperature control gas gap without any success in returning the temperature to the original levels. Both the temperature and resistivity of these samples were stable, at the new values, throughout the rest of the irradiation, Fig. 3-3.

Samples 1 and 3 , both alumina, did not exhibit a change in resistivity during the same time period. The temperatures for these samples are not known precisely since the thermocouples on both samples had previously falled. Comparison with the thermocouples on the other samples and on the tantalum heater indicate that their temperatures had also decreased. Sample 3 remained stable at a relatively low resistivity of about 6 Mohms $/ \mathrm{cm}$, Fig. 3-3. Sample 1 showed several sharp changes in resistivity from a steady 
Figure 3-3

\section{Triga Insulator Resistivity}

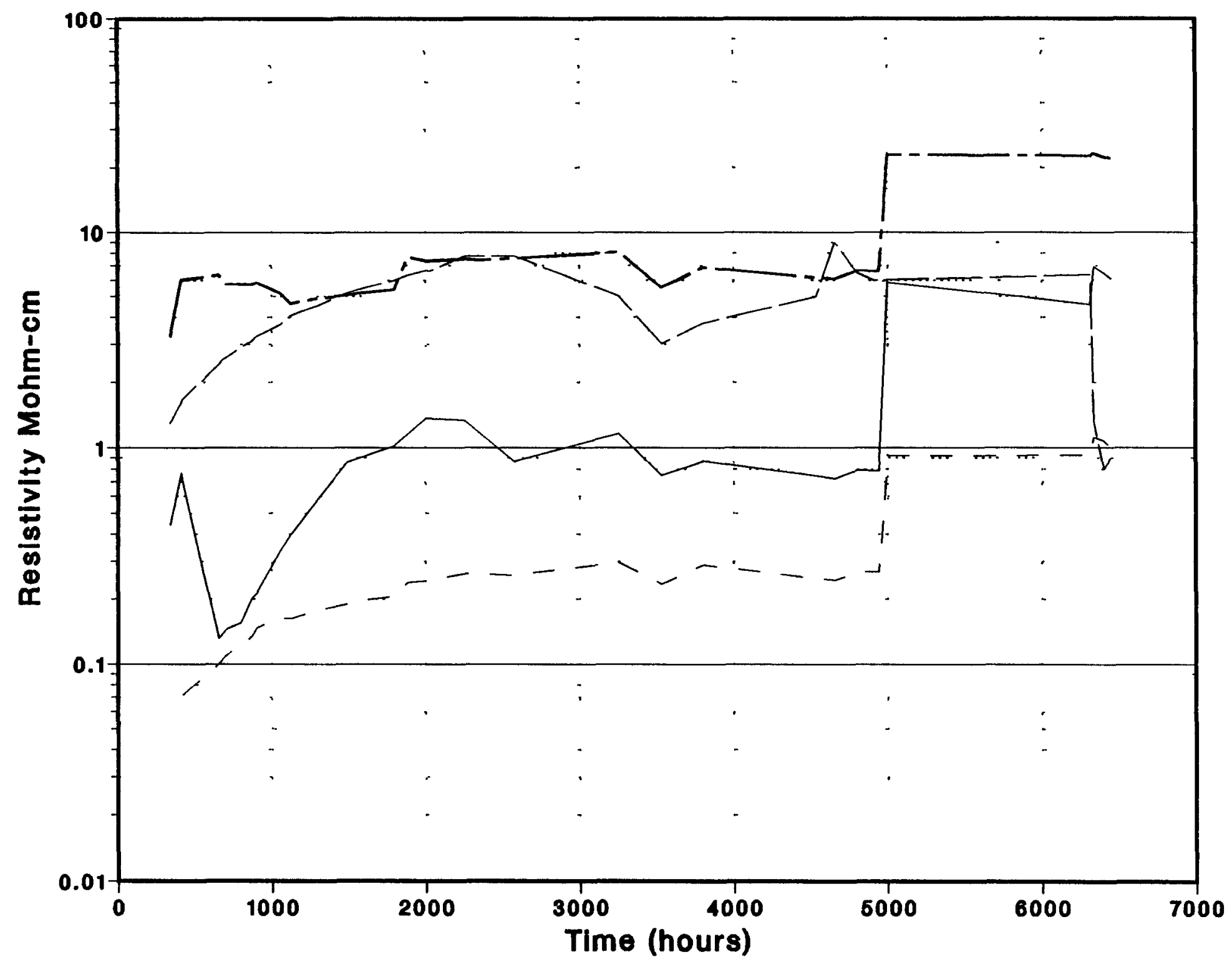

Legend 8 ample 2 sample 3 sample 4 samplo 5 
Figure 3-4

Triga Insulator Resistivity, sample 1

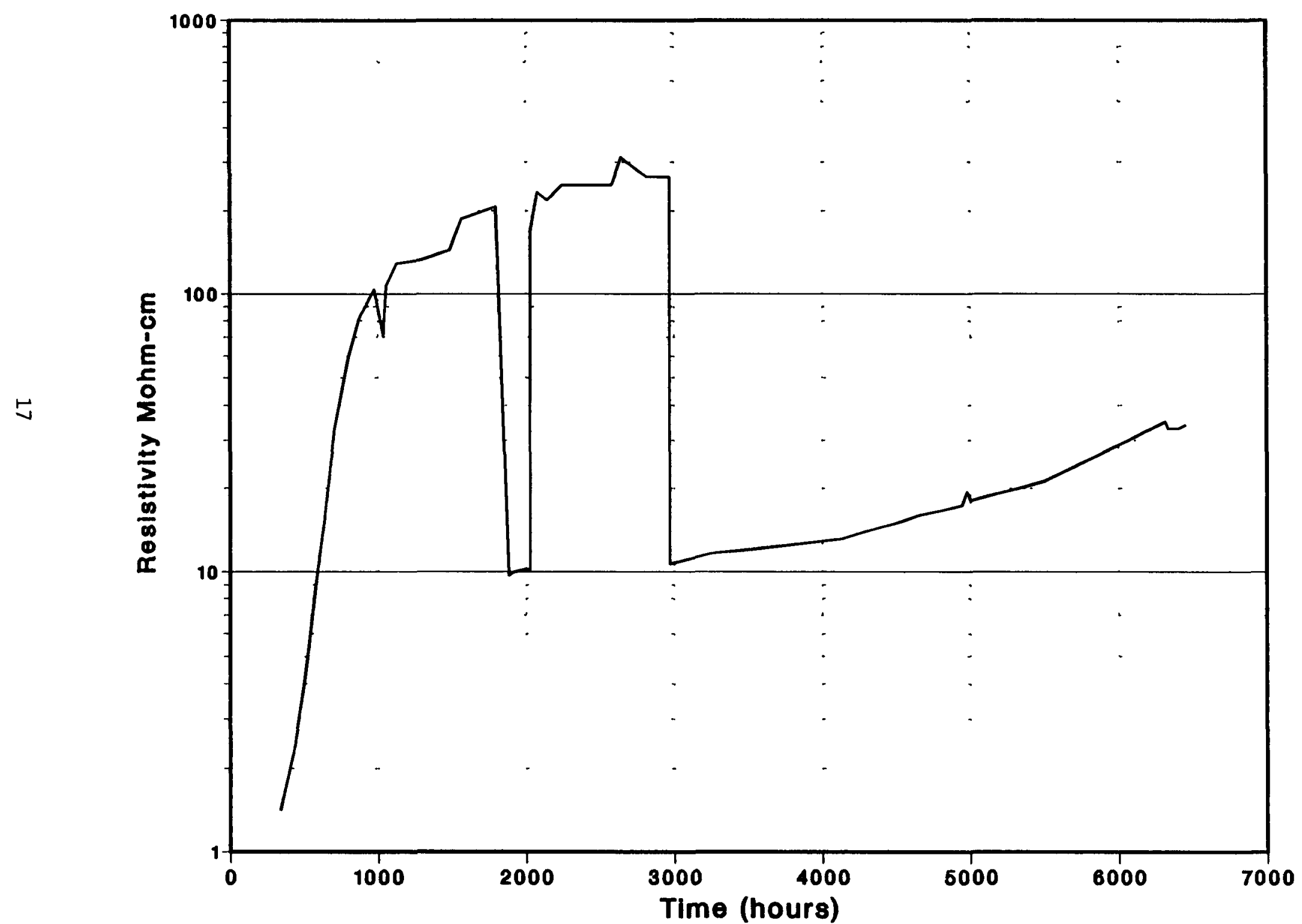


Figure 3-5

\section{Triga Insulator Temperature}

sample 2

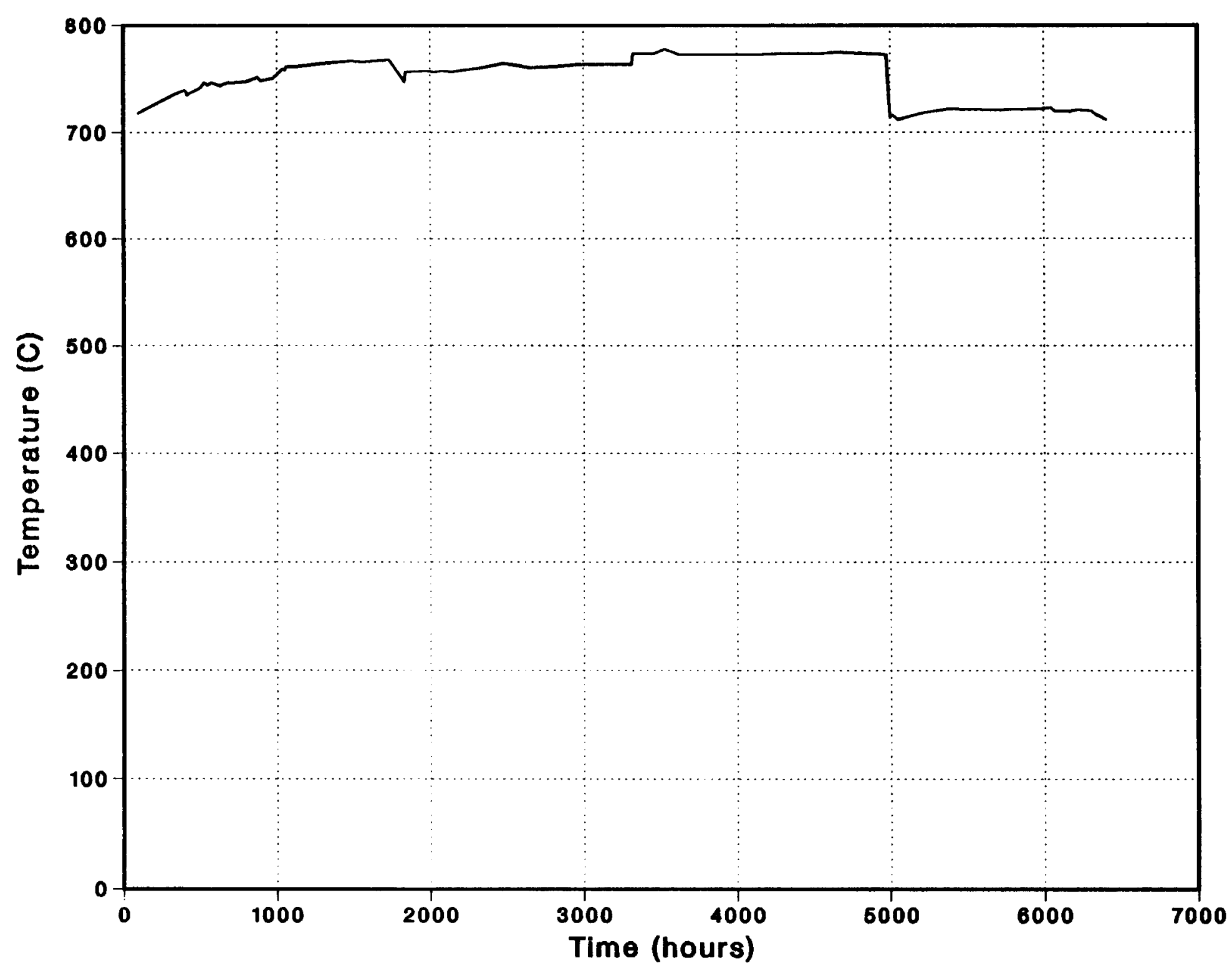


state value of about $230 \mathrm{Mohms} / \mathrm{cm}$ to about $10 \mathrm{Mohms} / \mathrm{cm}$ and then back again to $230 \mathrm{Mohms} / \mathrm{cm}$. Inftlally, the resistivity changed back to its original value as quickly as it had declined, Fig. 3-4. The last time the resistivity stayed at the low value and throughout the rest of the irradiation it was slowly increasing. The above sequence of events could be indicative of some foreign material that could have gotten lodged in the sample during one of the neutron radiography outages when the capsule was moved. This material could then have erratically shorted the voltage probe causing the erratic behavior.

\subsection{REMOVAL OF CAPSULE 4 FROM TRIGA MARK F CORE}

Shortly after the startup of August 7, 1986, the neutron radiographs taken during the outage were reviewed. During this revlew it was noticed that the gas gap between the tantalum heater and the water coolant cold finger was filled with some foreign substance. The radiograph was compared with the one previously taken on May 20, 1986 which showed a clearly defined and distinct gas gap, Fig. 3-6. The condition of the gas gap, as evidenced by the neutron radiograph, coupled with inconsistant sample and heater temperature levels for various gas gap pressures led to the conclusion that coolant water from the cold finger had reacted with the tantalum heater forming the foreign substance, probably $\mathrm{TaOH}$, which filled the gap. At this point it was decided to remove capsule 4 from service. The capsule was removed from the TRIGA Mark F core on August 13, 1986 after 6455 hours of irradiation testing. All sheath insulator samples were functioning about as expected at this time. A post irradiation examination of the samples is planned for FY-88. 


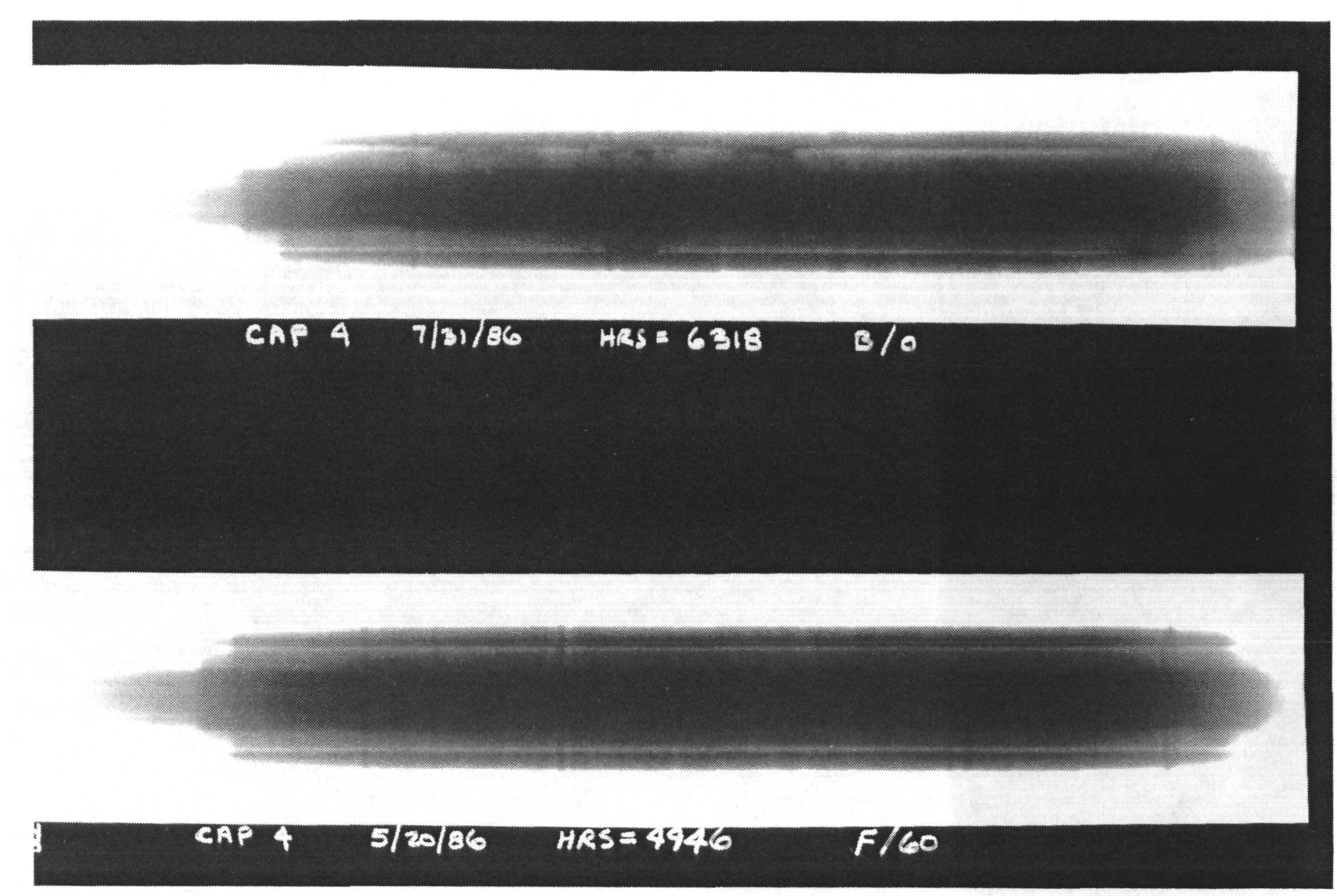

Figure 3-6. NR's of insulator capsule 
Test data interpretation of fueled emitter tests is concerned with improving the understanding and predictive capability of the fueled emitter lifetime models. During the SP-100 program, the LIFE-4 code was selected as the analytical tool for predicting the emitter lifetime. A calibrated version of the code was developed jolntly by Los Alamos National Laboratory (LANL), GA Technologies Inc. (GA), and Space Power Inc., (SPI). During FY-86 several areas were investigated to improve the calibrated version of the code. These were: first, gain a better understanding of the actual irradiation conditions of the diodes thus improving the input to the code; and secondly, compare the predicted with the measured emitter deformations from the periodic neutron radlographs to calibrate design analyses.

\subsection{TRIGA IRRADIATION CONDITIONS}

Work on establishing the actual irradiation conditions for the nine dlodes is continuing. The fuel pellet radial power distribution, the emitter axial temperature profile, and the real time operating power for the diodes are the mafor varlables which were investigated and subsequently used to modify the input to the LIFE code to improve its predictive capability.

The fuel pellet radial power distribution is an outcome of irradiating enriched $\mathrm{UO}_{2}$ fuel in a thermal reactor environment. As the U-235 enrichment increases, a larger fraction of the fissions occur on the outer perimeter of the fuel pellet (Fig. 4-1). This is in contrast to fast reactor irradiation where the radial power is essentially flat throughout the pellet thickness. The concentration of the fissions in the outer periphery of the pellet causes a greater damage fraction and swelling of the fuel in the region adjacent to the emitter which in turn leads to larger emitter distortions. It is for the above reason that irradiation in the TRIGA environment yields conservative results for code calibration.

The temperature of the emitter is not constant throughout its length. Depending on the configuration of the transition region on the upper portion 


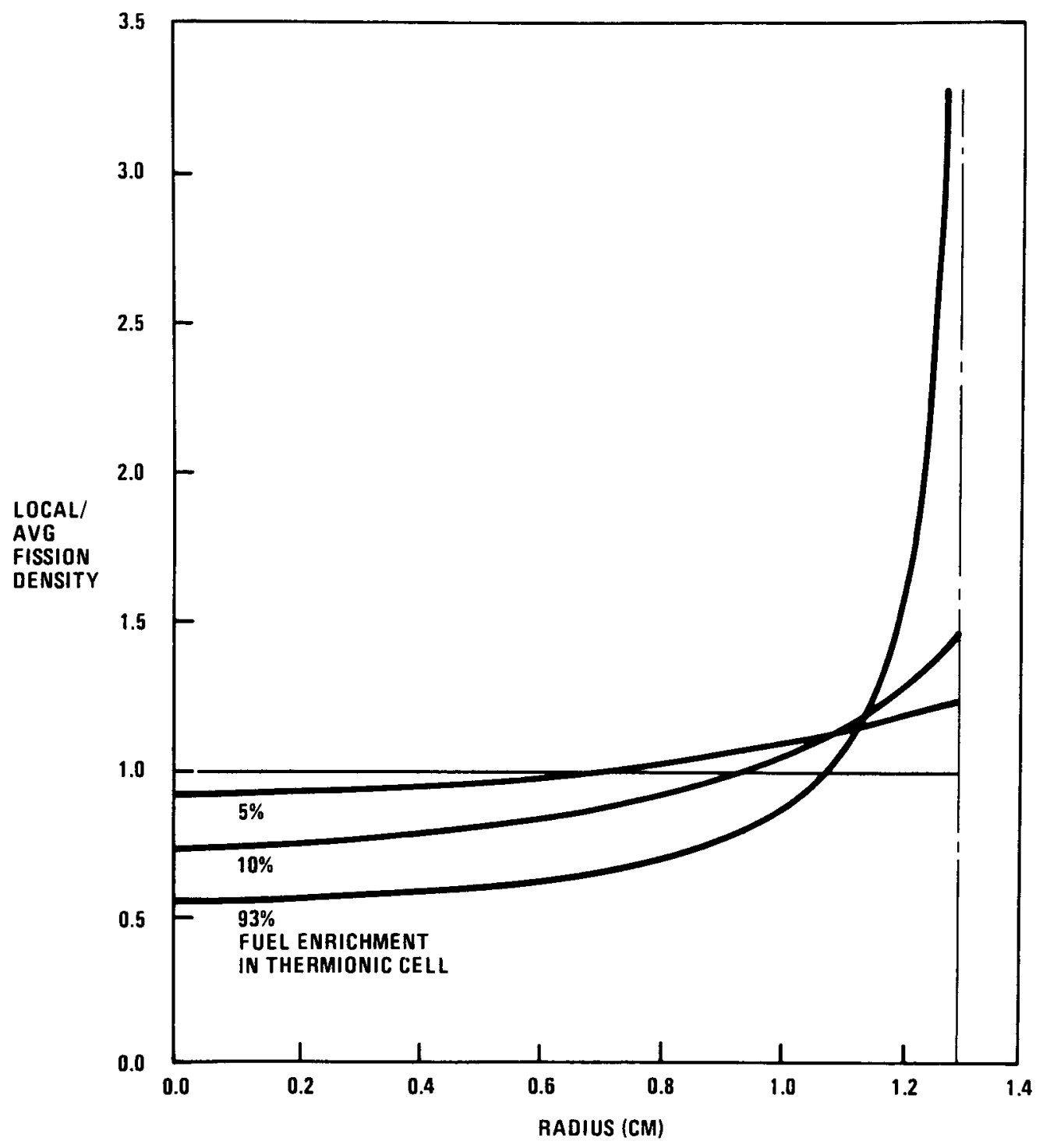

$G-335(45) R$

Figure 4-1. Thermionic cell fission power profiles 
and the radiation shields on the bottom, a temperature profile can be obtalned which varies by as mach as 30 to $50 \mathrm{~K}$ from the "average" emftter temperature. This "average" temperature is the temperature determined from the current/voltage (I/V) sweeps taken for each diode. These sweeps are based on results from ex-reactor tests of similar emitters which were run by Rasor Assoclates, Inc. (RAI), Ref 1. The results from these tests and the interpretations of the I/V sweeps is discussed further in the next section. The actual temperature profile of the diodes was determined analytically using TAC-2D, a two dimensional finite element code. A typical profile is shown in Fig. 4-2.

\subsubsection{Diode Operating Power}

Data gathered from on-line monitoring of the thermionic irradiation experiment during 1985 and 1986 is being reduced to obtain the operating history for the nine thermionic devices being tested. Two methods of data interpretation were used to obtain emitter temperature and diode power - two varlables not directly measurable.

Method 1 is based on RAI ex-reactor tests of similar diodes. These tests investigated the relationship between emitter temperature, ignition current, and voltage. The operating history for the in-core diodes is obtained by periodically taking current/voltage (I/V) sweeps of the diodes and using a correlation derived from the ex-reactor tests to determine the operating emitter temperature and diode power.

While this method yields the required operating data for each device, It relies on the results from the ex-reactor testing and the capability of each device to continue operating as a thermionic cell. If the I/V sweep of a device cannot be taken this method cannot yield the required data. Some of the devices on test have developed elther open or short circuits which prevents further I/V sweep data from beling collected. For example, both cells 1 and 3 of capsule 1 developed external shorts during 1986. An alternate method, method 2 , is being developed which uses collector temperature, an on-line continuously monitored data point, as the basepoint from which to calculate power and temperature for all devices whether they 


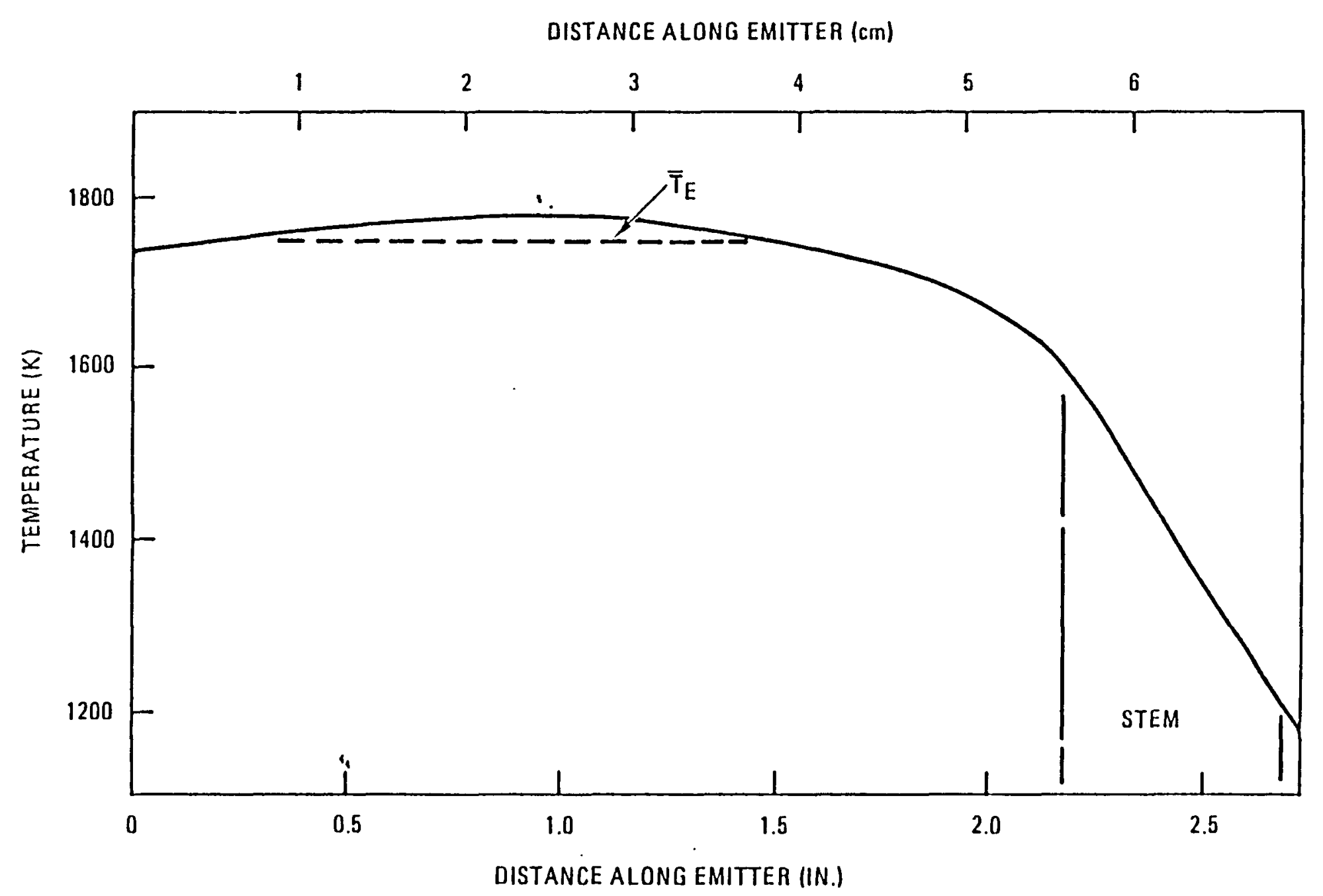

Figure 4-2. Typical emitter temperature profile. 
are operating as thermionic cells or not. This method would therefore extend both the lifetime and data gathered from the irradiation testing.

The diode power can be determined by considering a heat balance between the collector and the TRIGA pool. The power can be expressed as:

$$
\begin{aligned}
& P_{d}-I V=K\left(T_{c}-T_{w}\right) \\
& \text { where: } P_{d}=\text { diode power, watts } \\
& I=\text { diode current, amps } \\
& V=\text { diode voltage, volts } \\
& K=\text { thermal conductivity from the collector to the reactor } \\
& \quad \text { pool } \\
& T_{c}=\text { collector temperature, } K \\
& T_{w}=\text { TRIGA pool water temperature, } K
\end{aligned}
$$

This equation is applied just before and after a typical reactor shutdown. During this relatively short time, less than one week, the thermal conductivity between the collector to the reactor pool remains constant. Therefore, any changes in the dlode operating characteristics before and after the shutdown should be clearly observable. By applying the equation at each shutdown a history of the power and temperature for any device can be obtained. This method can then be baselined by using method 1 for regions where good, accurate I/V sweeps are available.

Figures 4-3, 4-4, and 4-5 show the operating history through 1986 for the middle diode of each capsule. The central diodes are representative of the capsule's behavior. The first two curves of each figure represent collector temperature (TC, K) and diode current (I, amps). These two parameters are on-line monitored and accurately known. The remaining curves showing diode power ( $\mathrm{Pd}, \mathrm{kW} / \mathrm{ft}$ ) and emitter temperature ( $\mathrm{Te}, \mathrm{K})$ were calculated using the described methods 1 and 2 .

Some general trends shown by these curves and observed for all diodes are worth noting. Collector temperatures for all nine dlodes slowly 
CAPSULE I CELL 2 HISTORY: COMPARISON OF CALCULATIONAL METHODS
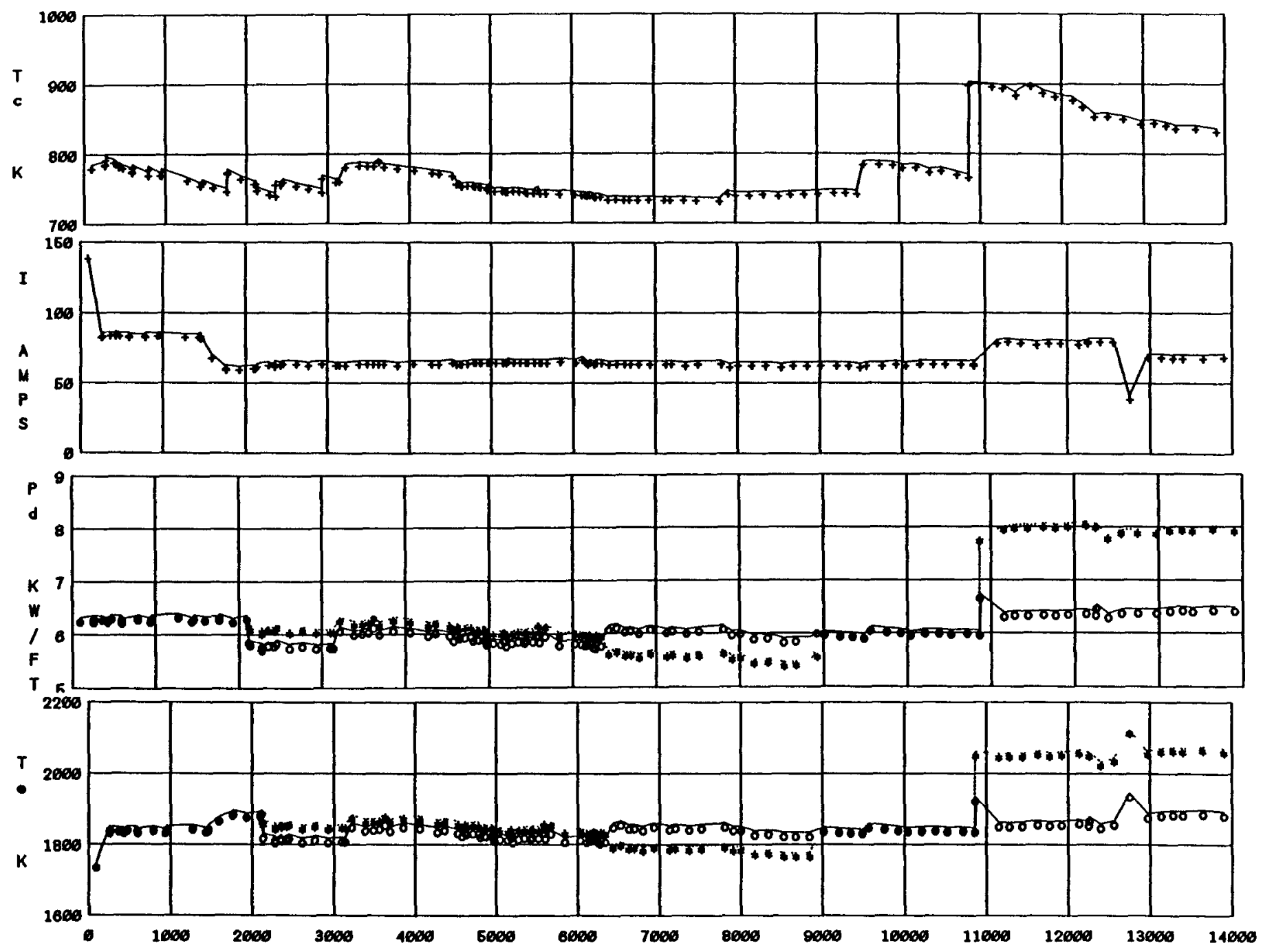

HOURS ON LINE

- - METHOD 1: IV CORRELATION

- METHOD 2: TC CDRRELATION

- on-line measured value 
Figure 4-4

CAPSULE 2 CELL 2 HISTORY: COMPARISON OF CALCULATIONAL METHODS
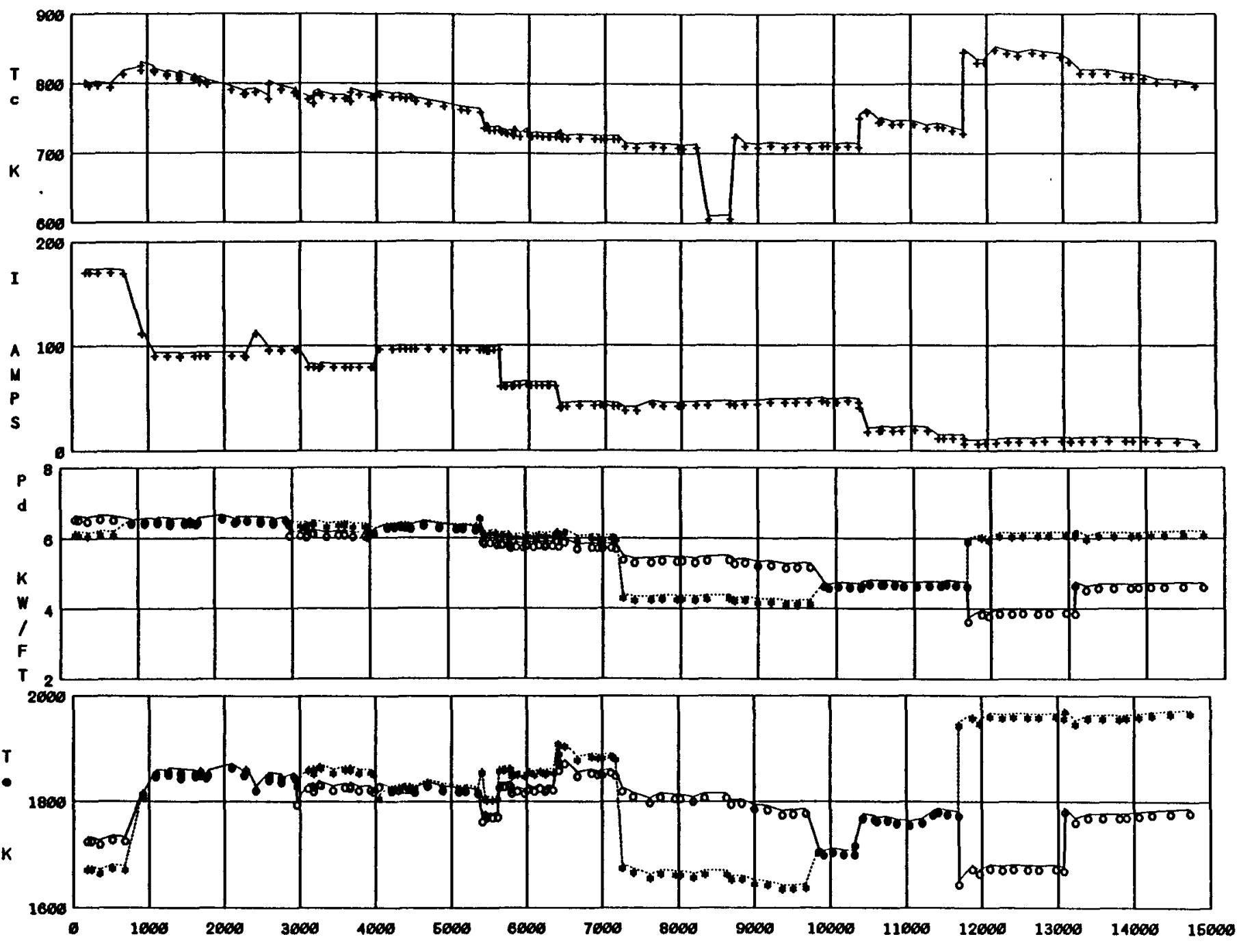

HOURS ON LINE

-o- METHOD 1: IV CORRELATION

*....... METHOD 2: TC CORRELATION

- on-line measured value 
CAPSULE 3 CELL 2 HISTORY: COMPARISON OF CALCULATIONAL METHODS
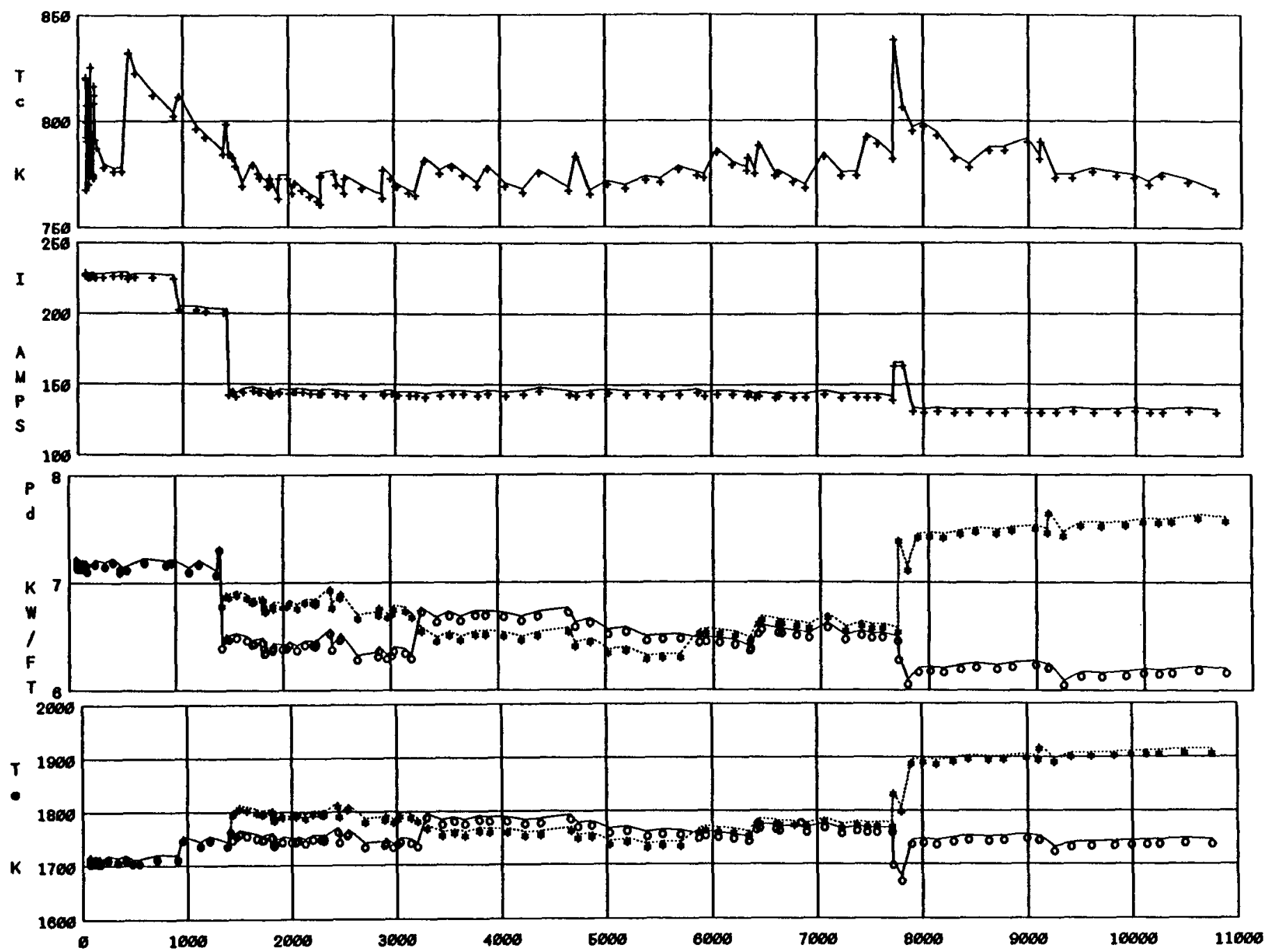

HOURS ON LINE

- METHOD 1: IV CORRELATION
-......... METHOD 2: TC CORRELATION

- on-line measureo value 
decreased during 1985 operation. This is attributed to gas buildup in the lower secondary capsule containment. This gas enhances heat transfer from the collector to the reactor pool. During 1985, as gas built up we saw a decrease in collector temperature. Early in 1986, periodic purging of the lower secondary was inftiated to prevent this buildup. Thus we see an end to this downward trend in collector temperature.

Method 2 show that all nine cells appear to be operating at higher power levels (and correspondingly higher emitter temperatures) by the end of 1986. The predicted higher temperature is supported by both the collector temperature and diode current data gathered during the perfod. For many cells, the collector temperature was higher towards the end of 1986 than at any other time during the previous two years of irradiation. Similarly, dlode current was high indicating that electron cooling was being increased in response to higher emitter temperatures being predicted by the $I / V$ sweeps. These studies are continuing with further analysis of the above as well as new 1987 data. An existing two-dimensional steady state heat transfer model for a typical thermionic diode is being used to correlate the two methods.

\subsection{LIFE CODE RESULTS}

The results of modifying the input to the LIFE code for the pellet radial power distribution, emitter axial temperature profile, and linear power history as explained in the previous sections show a good approximation to the actual deformation for most of the diodes. A set of curves showing the LIFE predicted and the measured deformation from neutron radiographs (NRs) is shown in Figs. 4-6 through 4-14 for the nine diodes. The band for the measured deformations shows the range in measurements over the length of the diode for each NR. The curves generally exhibit a good relation of predicted vs. measured deformations indicating that the code is predicting the emitter distortions accurately up to this point in the Irradlation. Only two cells are exhibiting non-typical deformation behavior. These are capsule 1 cell 3 and capsule 3 cell 1 . 


\section{Deformation Analysis}

Capsule 1 Cell 1

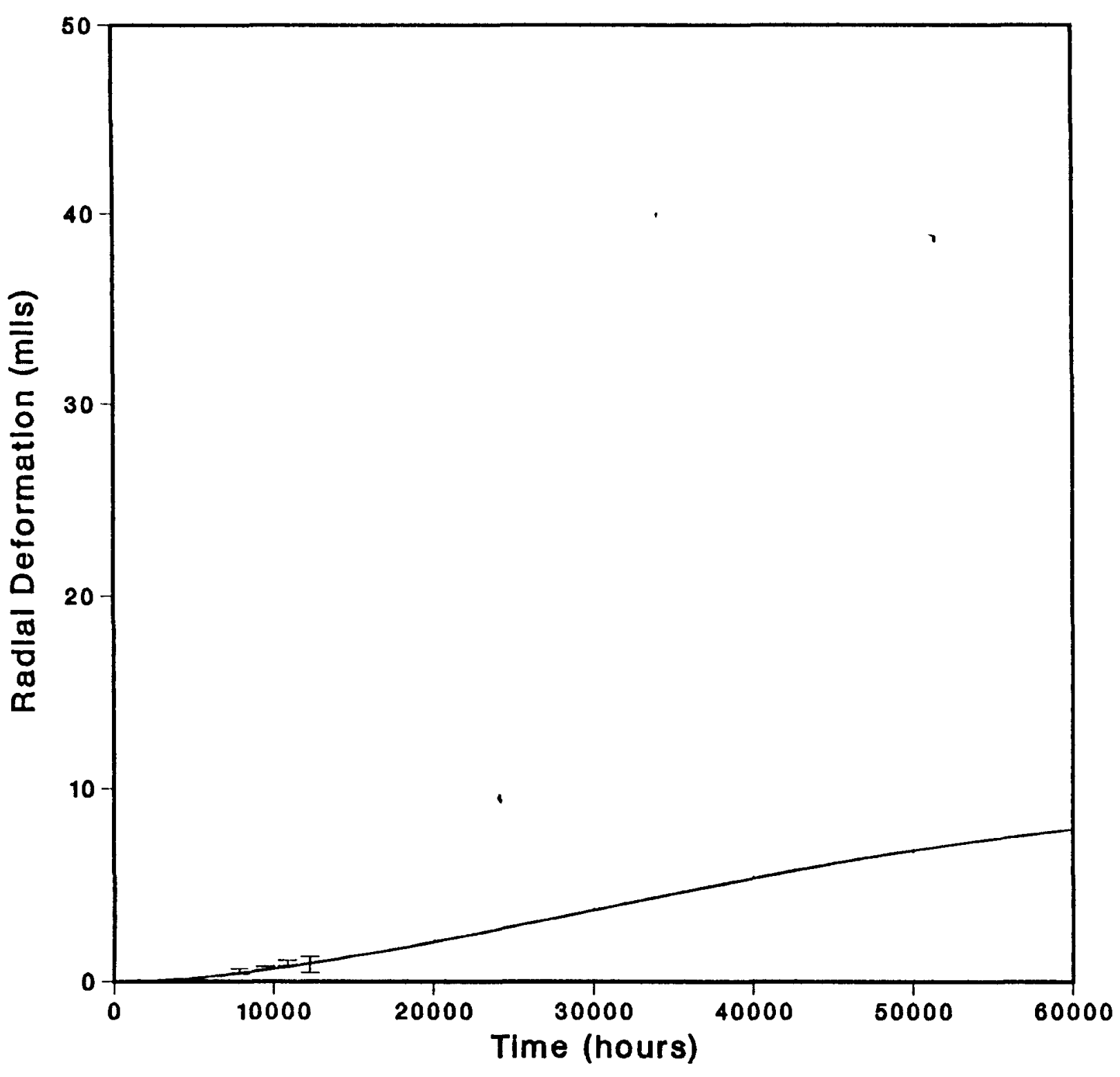
Emltter OD
Emitter Thickness
1.100 In
Irrad Time
0.100 in
Emitter Temp $12250 \mathrm{hr}$ $1750 \mathrm{~K}$

Legend calculated

- experimental 
Figure 4-7

Deformation Analysis

Capsule 1 Cell 2

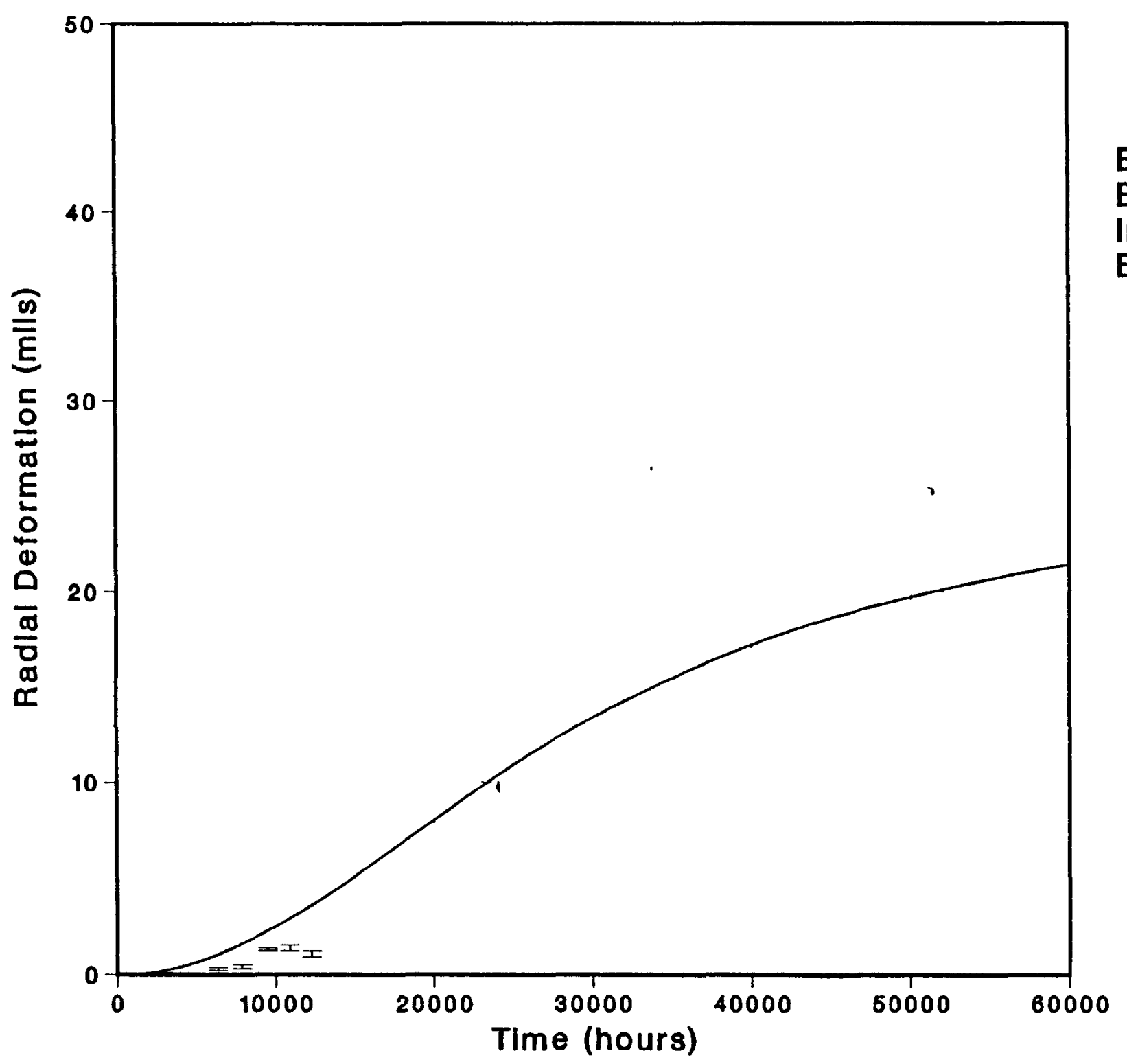

Emlter OD

Emitter Thickness

Irrad Time

Emitter Temp
1.100 In

0.100 in $12250 \mathrm{hr}$ $1850 \mathrm{~K}$
Legend calculated

- experimental 
Figure 4-8

\section{Deformation Analysis Capsule 1 Cell 3}

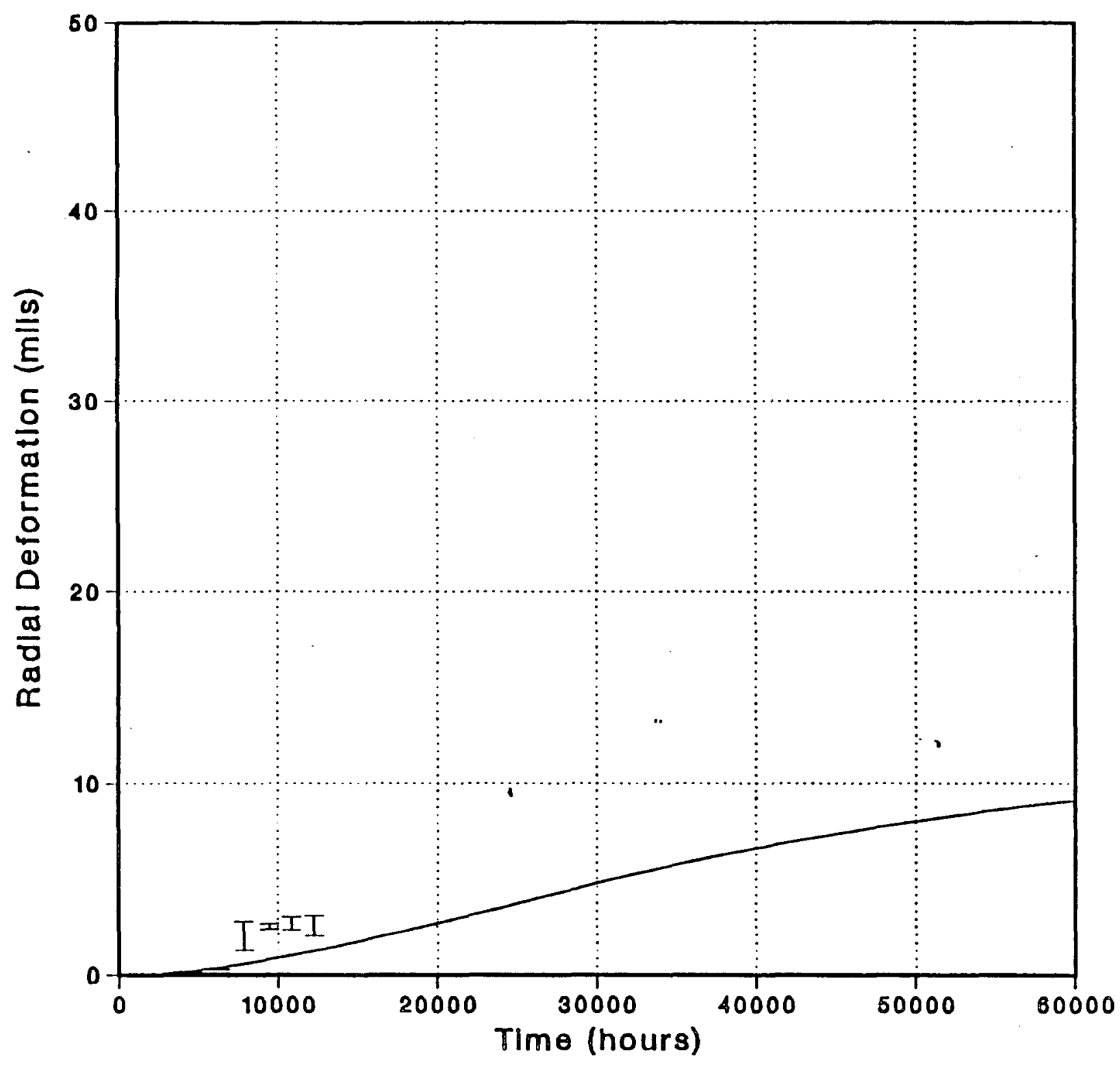

$\begin{array}{ll}\text { Emitter OD } & 1.100 \mathrm{In} \\ \text { Emitter Thickness } & 0.100 \mathrm{in} \\ \text { Irrad Time } & 12250 \mathrm{hr} \\ \text { Emitter Temp } & 1750 \mathrm{~K}\end{array}$

Legend

calculated

- experlmental

Figure 13 


\section{Deformation Analysis \\ Capsule 2 Cell 1}

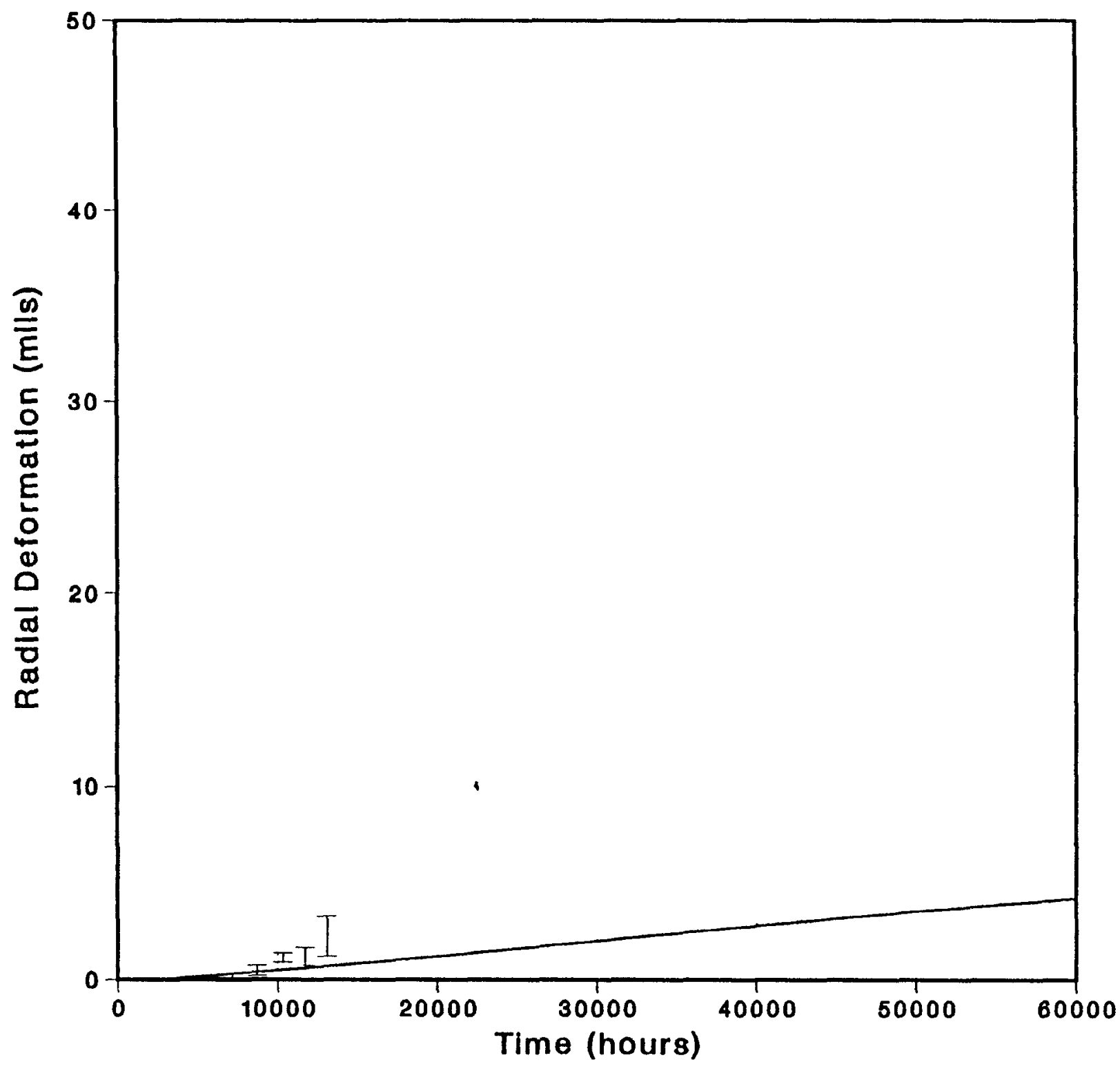

$\begin{array}{ll}\text { Emltter OD } & 1.100 \mathrm{ln} \\ \text { Emitter Thickness } & 0.070 \mathrm{in} \\ \text { Irrad Time } & 13080 \mathrm{hr} \\ \text { Emitter Temp } & 1650 \mathrm{~K}\end{array}$

Legend

calculated

- experlmental 


\section{Deformation Analysis \\ Capsule 2 Cell 2}

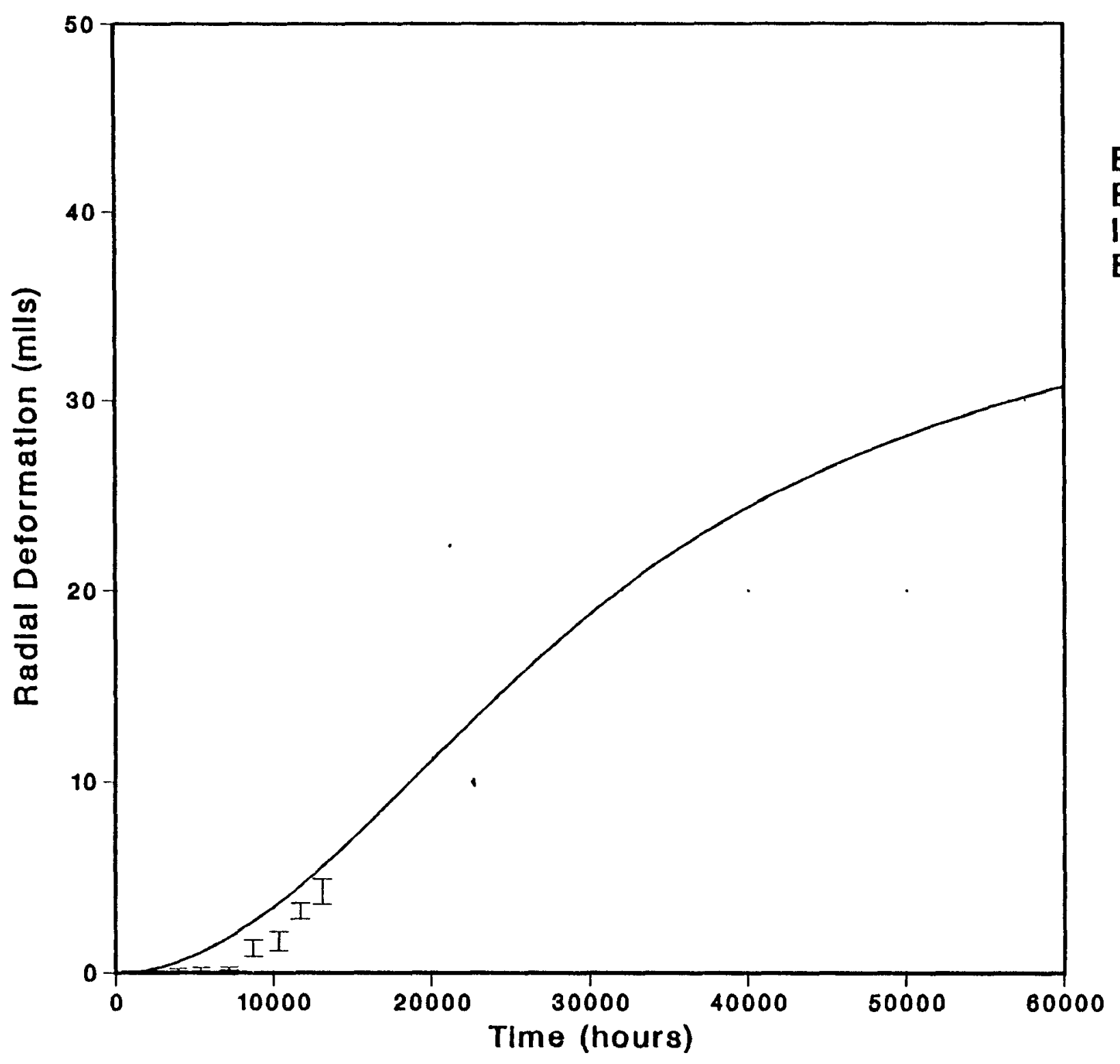

$\begin{array}{ll}\text { Emltter OD } & 1.100 \mathrm{In} \\ \text { Emitter Thickness } & 0.070 \mathrm{in} \\ \text { Irrad Time } & 13080 \mathrm{hr} \\ \text { Emitter Temp } & 1850 \mathrm{~K}\end{array}$

Legend calculated

- experimental 


\section{Deformation Analysis \\ Capsule 2 Cell 3}

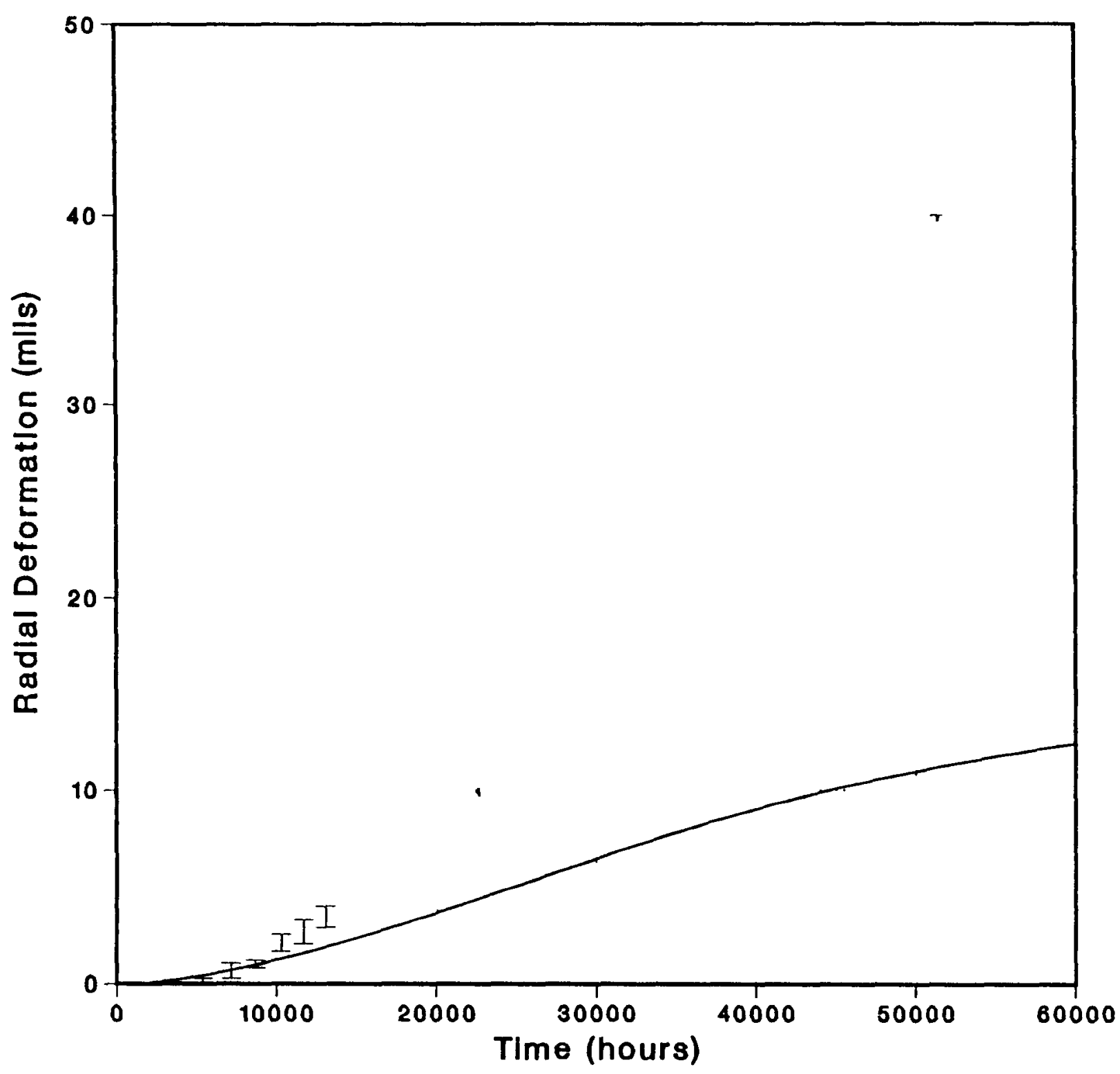

Emltter OD $\quad 1.100$ in

Emitter Thickness 0.070 in

Irrad TIme $13080 \mathrm{hr}$

Emitter Temp $1750 \mathrm{~K}$

\section{Legend}

calculated

- experimental 


\section{Deformation Analysis} Capsule 3 Cell 1

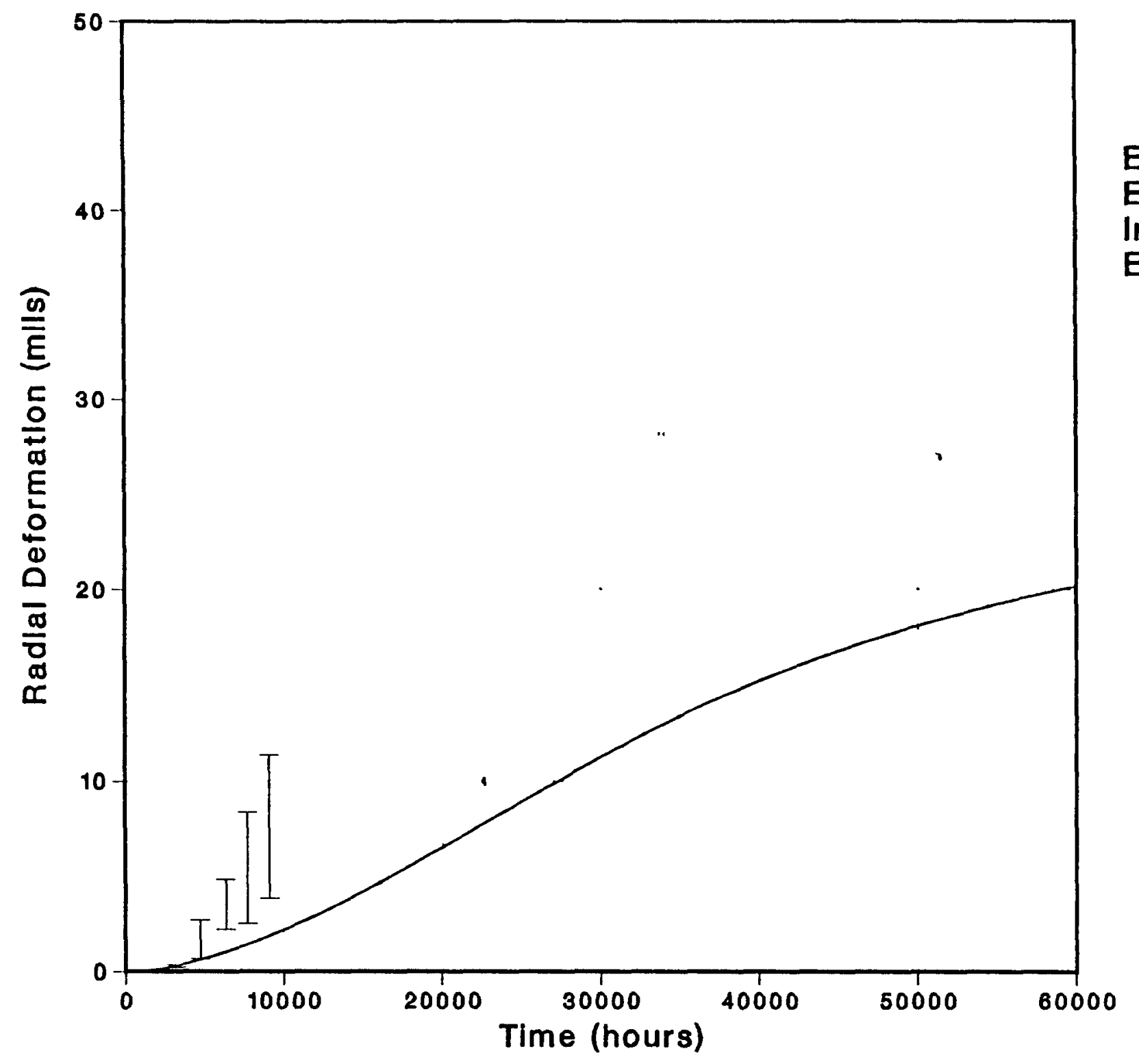

$\begin{array}{ll}\text { Emltter OD } & 1.100 \mathrm{In} \\ \text { Emitter Thickness } & 0.040 \mathrm{in} \\ \text { Irrad Time } & 9105 \mathrm{hr} \\ \text { Emitter Temp } & 1750 \mathrm{~K}\end{array}$

\section{Legend}

calculated

- experimental 


\section{Deformation Analysis Capsule 3 Cell 2}

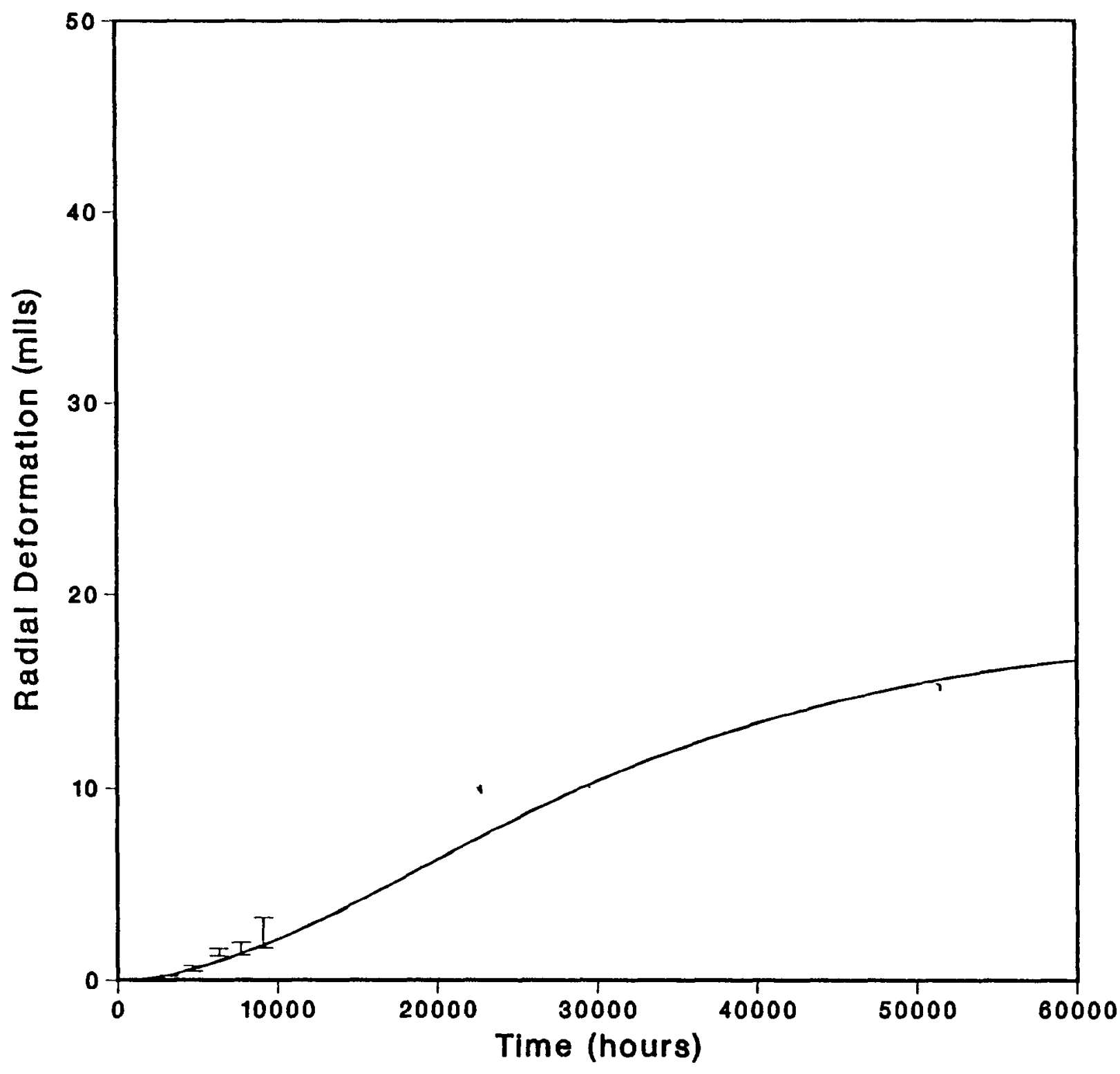

$\begin{array}{lll}\text { Emltter OD } & 1.100 \mathrm{ln} \\ \text { Emitter Thickness } & 0.070 \mathrm{in} \\ \text { Irrad Time } & 9105 \mathrm{hr} \\ \text { Emitter Temp } & 1750 \mathrm{~K}\end{array}$

Legend calculated

- experimental 


\section{Deformation Analysis}

Capsule 3 Cell 3

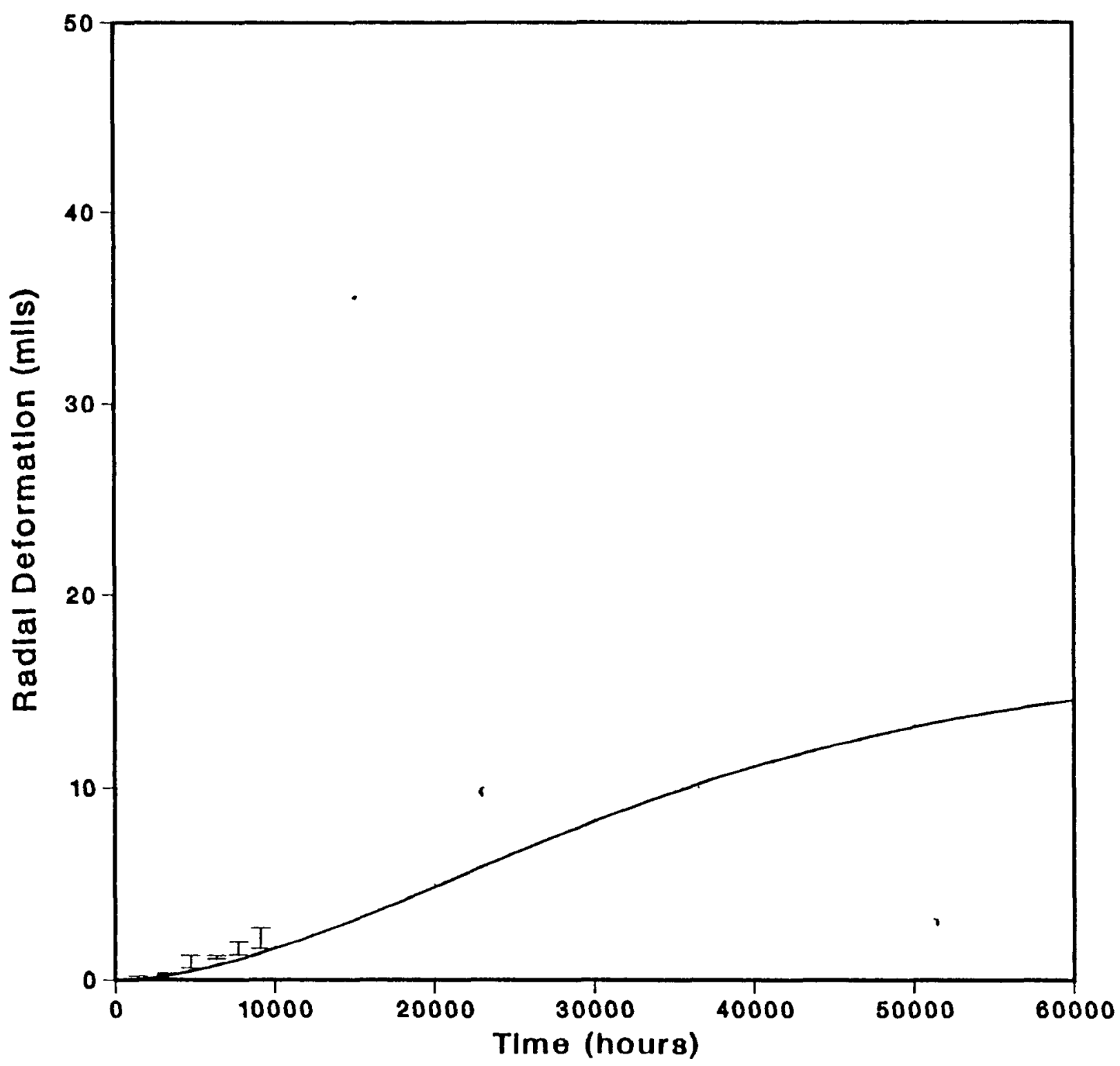

$\begin{array}{lll}\text { Emltter OD } & 1.100 \mathrm{ln} \\ \text { Emitter Thickness } & 0.070 \mathrm{in} \\ \text { Irrad TIme } & 9105 \mathrm{hr} \\ \text { Emitter Temp } & 1750 \mathrm{~K}\end{array}$

\section{Legend}

calculated

- experimentel 
Capsule 1 cell 3 showed a distinct, sharp increase in deformation at about 6500 hours, Fig. 4-7. This increase was a one time effect and close scrutiny of the NRs since then have not shown any further anomalous behavior. Capsule 3 cell 1 has shown greater than expected deformation since about 5000 hours, Fig. 4-8. The range of deformations over the length of the emitter is also large. A study of the NR showed that this emitter is deforming in an "hour glass" pattern as opposed to the general "barrel shape" pattern of the others. This is shown in Fig. 4-15 which is a plot of the measured deformations over the length of the emitter at the various NRs. This pattern of anomalous behavior is probably caused by a defect during the manufacture of the diode. 
Figure 4-15

\section{Local Emitter Distortion \\ Capsule 3, Cell 1}

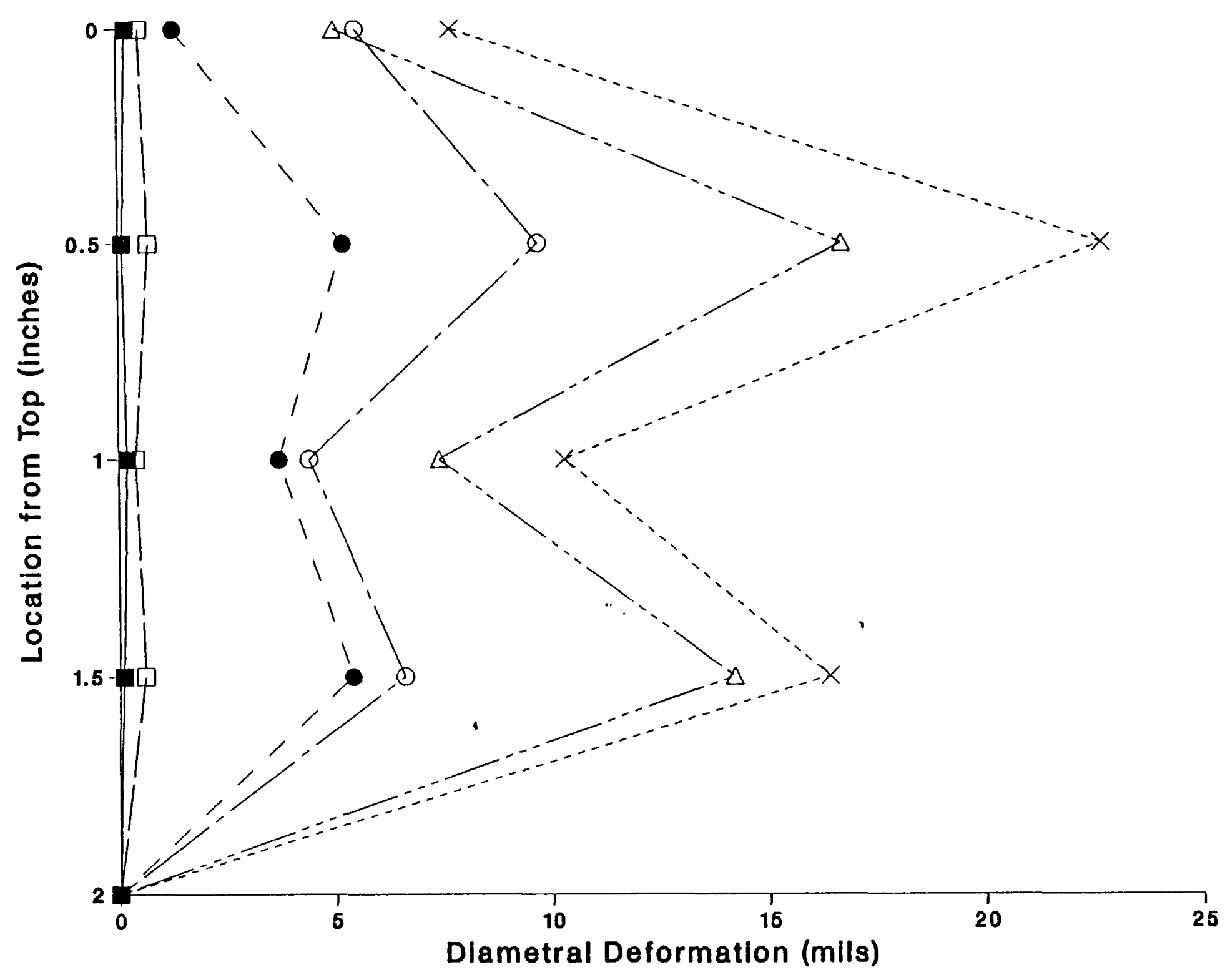

\section{Legend}

1413.3 Hours

$\square \quad 3197.8$ Hours

- 4718.6 Hours

O 6344.5 Hours

$\triangle 7716.0$ Hours

$\times \quad 9105.0$ Hours

Datafile led31.dat 


\section{NEUTRON RADIOGRAPHY}

Neutron radiography (NR) is the primary means for obtaining periodic emitter distortion data which can be used for calibrating/validating the LIFE computer code. The process is routinely and quickly carried out with the TRIGA Mark F. A typical NR run for 9 diodes can be accomplished in less than 5 working days. Several improvements both in the operations and interpretations of the NRs were made in the reporting period which improve our confidence in the emitter distortion data taken.

\subsection{NEUTRON RADIOGRAPHY PROCEDURE}

Neutron radlographs of the three capsules are taken at periodic intervals which range from 1500 to 2500 hours. A series of six exposures are taken of each capsule, three angular positions at each of two elevations, Fig. 5-1. Exposing each capsule individually and taking the NRs at two elevations has markedly improved the geometry of the system which together with the other changes outlined below have improved the quality of the NRs.

The exposures involve irradiating foils of indium and dysprosium and a sheet of Track-etch film. Following the exposure, the foils are placed in a vacuum cassette on sheets of Industrialex film. The film is then developed to get the NR exposure, Fig 5-2. The design and fabrication of the vacuum cassette was a change made during the reporting period which greatly 1mproved the positioning and contact between the foils and the film, thus ylelding a much sharper image with a greater resolution of the sharp edges making the NR much more legible. The Track-etch film is developed but not read. Due to the uncertainty in the availability of the film and a lack of reading equipment, densitometer with computer software, 1t was suggested to DOE-SAN that once the current stock of $f 11 \mathrm{~m}$ runs out no further Track-etch exposures will be taken.

The NR reading is done manually using a "light box" with a lox eye piece on a traveling lead screw. The lead screw is attached to a digital linear transducer whose output is directed to a dedicated PC for data 


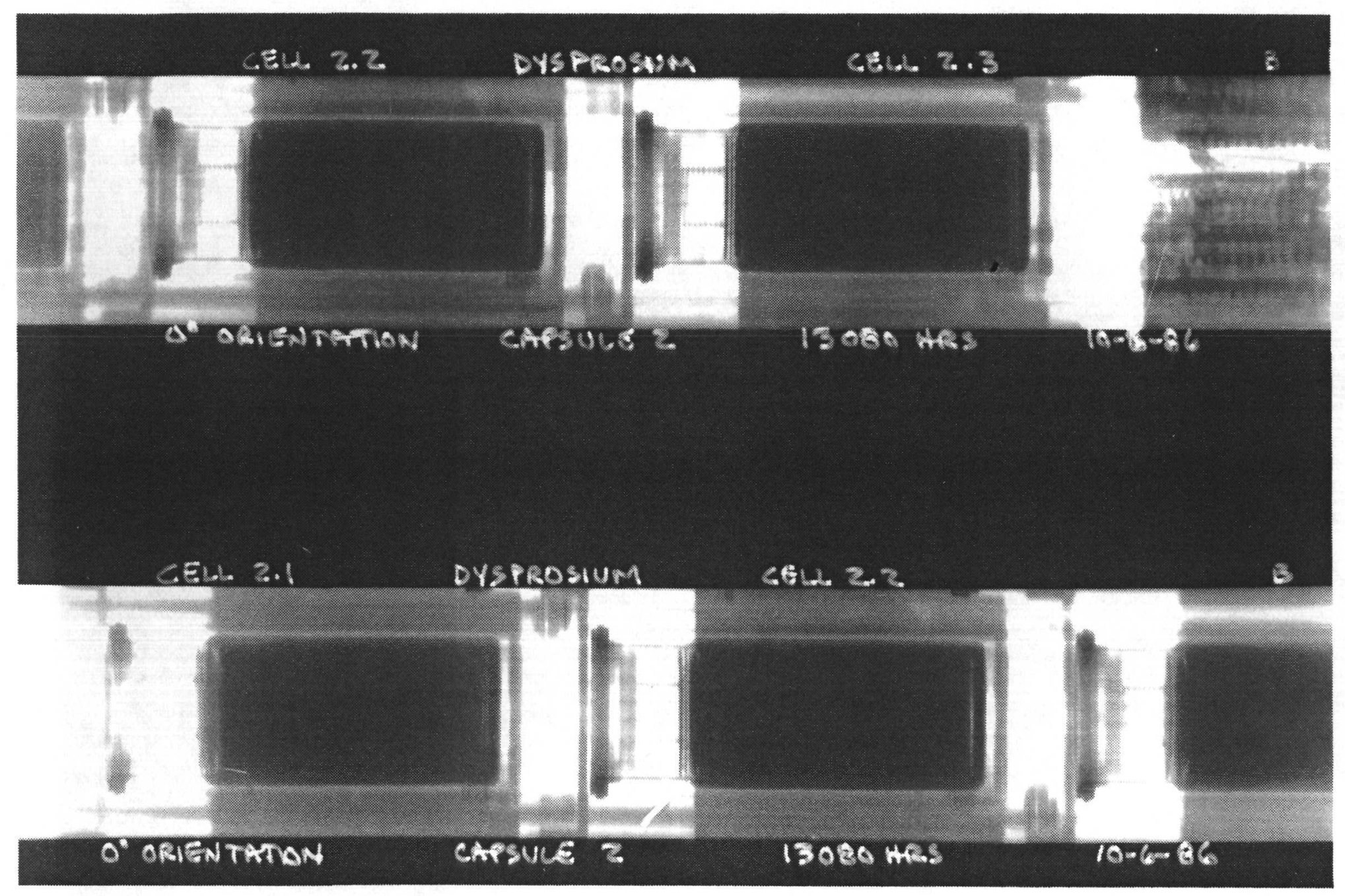

Figure 5-2. Typical NR exposure for Capsule 2 
recording and storage. Data is taken at the base and at four equally

spaced elevations along the length of the diode. The base reading is used as the standard for determining the diameter changes at the other

elevations. The output from the NRs for each diode is similar to the plot for capsule 3 cell 1 shown in Fig. 4-15.

Since the improvements made during the system geometry, operation, and interpretation, primarily using the same operator to read the exposures, we have been able to get excellent readings from the NRs which are about $+1-$ 0.001 in accuracy. 
APPENDIX A

THERMIONIC DIODES IRRADIATION HISTORY 
The following list summarizes the startups, shutdowns and scrams for the thermionic capsule system presently under test in the Mark F TRIGA reactor.

1. 13 Jan 85 @ 2300 hrs; Capsule 2 at power.

2. 14 Jan 85 e 1101 hrs; Scram due to TRIGA system (bad thermocouple). Back up to power at about $1630 \mathrm{hrs}$ on same day after fixing $T / C$.

3. 17 Feb 85 e 0700 hrs; Shutdown for neutron radiography (N-R) and capsule 1 installation.

4. 21 Feb 85 @ 2130 hrs; Capsules 1 and 2 at power.

5. 23 Apr 85 @ 0101 hrs; Scram due to TRIGA system (bad GM tube in continuous air monitor). Back up to power at about $1130 \mathrm{hrs}$ on same day.

6. 6 May 85 e 0427 hrs; Scram (suspect sfte power problem). Back up at about $1200 \mathrm{hrs}$ on same day.

7. 21 May 85 e 0830 hrs; Shutdown for N-R.

8. 28 May 85 @ 1900 hrs; Capsules 1 and 2 back at power (at about 2 inches from bottom of core).

9. 11 Jun 85 @ 0900 hrs; Lowered capsules 1 and 2 to 1 inch from bottom of the core position that had been used before May 21, 1985.

10. $2 \mathrm{Jul} 85$ \& $1309 \mathrm{hrs;}$ TRIGA control rod magnet problem. At about $500 \mathrm{~kW}$ for about $10 \mathrm{~min}$. Added air conditoner to cool control rod magnets in hot weather.

11. 10 Jul 85 e 0900 hrs; Shutdown for $N-R$ and capsule 3 installation. 
12. $19 \mathrm{Jul} 85$ e $1600 \mathrm{hrs}$; Capsules 1,2 and 3 at power.

13. 8 Aug 85 e $0311 \mathrm{hrs;} \mathrm{Scram} \mathrm{(suspect} \mathrm{site} \mathrm{power} \mathrm{problem).} \mathrm{Backup} \mathrm{at} \mathrm{about}$ 1300 hrs on 9 Aug 85.

14. 17 Sep 85 \& 1430 hrs; Shutdown for $N-R$ and capsule 4 Installation.

15. 27 Sep 85 \& 1500 hrs; Capsules $1,2,3$ and 4 at power.

16. 28 Sep 85 e $0350 \mathrm{hrs;} \mathrm{Scram} \mathrm{due} \mathrm{to} \mathrm{low} \mathrm{bus} \mathrm{bar} \mathrm{coolant} \mathrm{flow} \mathrm{for} \mathrm{cell} 3$ of capsule 2. Removed air bubble(s) and returned to power at about $1500 \mathrm{hrs}$ on sameday.

17. 14 Oct 85 \& $1109 \mathrm{hrs}$; Scram due to low bus bar coolant flow for cell 3 of capsule 2. Removed air bubble(s) and returned to power at about $1600 \mathrm{hrs}$ on same day.

18. 15 Oct 85 e 0024 hrs; Scram due to low bus bar coolant flow for cell 3 of capsule 2. Removed air bubble(s) and reduced sensitivities of the infra-red optical low flow sensors. Returned to power at about $2200 \mathrm{hrs}$ on same day.

19. 16 Oct 85 e 0017 hrs; Scram due to low bus bar coolant flow for cell 1 of capsule 1. The water coolant loop for the capsule 4 cold finger was separated from the bus bar coolant A separate pump and filter using the Mark F pool water was installed. Returned to power at about 2230 on 17 oct 85 .

20. 24 Oct 85 e $1807 \mathrm{hrs}$; Scram due to low cold finger coolant flow. The capsule 4 cold finger coolant loop was replumbed into the existing resistive load coolant system, air (gas) eliminators added to this system, and the cold finger low flow scram system changed to require a two-out-of-two colncldence on two parallel flow paths. Returned to power at about $1330 \mathrm{hrs}$ on 
21. 14 Nov 85 \& 0103 hrs; Scram due to high flux on linear power channel K2. Replaced sticky control rod switch on reactor console and returned to power at about $1500 \mathrm{hrs}$ on the same day.

22. 16 Dec 85 e 0650 hrs; Shutdown for N-R via a manual scram.

23. 29 Dec 85 \& 1524 hrs: Back at power.

24. 11 Jan 86 @ $0619 \mathrm{hrs;}$ Scram due to low bus bar coolant flow for cell 1 of capsule 1. Removed gas bubble(s) introduced by a water filter inspection and returned to power at about 0945 hrs on the same day.

25. 16 Feb 86 a 1302 hrs: Scram due to low bus bar coolant flow for cell 1 of capsule 3. Cautioned thermionic personnel to not step on bus bar coolant lines, ordered a larger bridge over the bus bar coolant lines for insta11ation at the next shutdown and returned to power at about $1530 \mathrm{hrs}$ on the same day.

26. 3 Mar 86 e 0645 hrs; Shutdown for N-R.

27. 11 Mar 86 @ $1350 \mathrm{hrs;} \mathrm{Back} \mathrm{at} \mathrm{power.}$

28. 17 Apr 86 @ 1243 hrs; Scram due to test of new Mark F console alarm system which overloaded thermionic scram bus. Back at power at about $1540 \mathrm{hrs}$ on same day.

29. 18 May 86 @ 0852 hrs; Shutdown for N-R.

30. 27 May 86 e 1200 hrs; Back at power.

31. 31 May 86 e 1754 hrs; Scram due to low gas gap pressure in Capsule 4 due 
to a bad 5.63 VDC instrument power supply. Various erratic pressure transducer readings over the last six months or so were apparently due to this power supply.

32. 2 Jun 86 e 1754 hrs; Back at power after replacing power supply.

33. $22 \mathrm{Jul} 86$ @ $1650 \mathrm{hrs;}$ Scram due to power flucuation (lightening strike on site).

34. $23 \mathrm{Jul} 86$ e $1100 \mathrm{hrs;}$ Back at power.

35. $28 \mathrm{Jul} 86$ e $0700 \mathrm{hrs;}$ Shutdown for $\mathrm{N}-\mathrm{R}$ and annual Mark F reactor fuel element inspection.

36. 7 Aug 86 e $1840 \mathrm{hrs;} \mathrm{Back} \mathrm{at} \mathrm{power.} \mathrm{The} \mathrm{Mark} \mathrm{F} \mathrm{core} \mathrm{was} \mathrm{changed} \mathrm{from} 103$ fuel elements plus 5 control rods (with fuel followers) to 97 fuel elements and 5 control rods. The core excess reactivity changed from $\$ 1.60$ on $28 \mathrm{Ju} 186$ (control rods at 611 units) to $\$ 0.39$ on 10 Aug 86 (control rods at 732 unfts). The reactor power input to the HP data acquisition system was changed from excore detector $\mathrm{K} 2$ to Incore $\mathrm{Rh}$ selfpowered detector SPD1 and normalized to the Mark F console power at $1400 \mathrm{Kw}$ based on the new power calibration of 7 AUG 86 .

37. 13 Aug 86 e 0715 hrs; Shutdown to remove Capsule 4 (Insulators) whlch had developed an internal water leak. Back at power at about 1400 hrs on same day after removal of 4 more fuel element from the periphery of the core. No new power calibration was done. The core excess was $\$ 0.53$ (control rods at 715 units) on 16 Aug 86 . Now have 94 fuel elements and 5 control rods in the Mark F core. 
38. 19 Aug 86 e 0504 hrs; Scram due to Mark F high voltage power supply. Back at power at about $1040 \mathrm{hrs}$ on same day after replacing the Mark F power supply.

39. 24 Aug 86 e 0643 hrs; Scram due to Mark F high voltage power supply.

40. 25 Aug 86 e 1100 hrs; Back at power after repalring K2 channel coaxial connector at reactor room bulkhead.

41. 6 Oct 86 e 0715 hrs; Shutdown for N-R.

42. 14 Oct 86 e $1300 \mathrm{hrs;} \mathrm{Back} \mathrm{at} \mathrm{power.}$

43. 23 Dec 86 @ 1430 hrs; Shutdown for Christmas holiday.

44. 5 Jan 87 e $1430 \mathrm{hrs;}$ Back at power. 